ICIP WORKING PAPERS:
$2012 / 7$

Social media and political

change: The case of the 2011

revolutions in Tunisia and

Egypt

Regina Salanova

INSTITUT

CATALÀ

INTERNACIONAL

PER LA PAU 


\section{Social media and political change: The case of the 2011 revolutions in Tunisia and Egypt}

Regina Salanova

Institut Català Internacional per la Pau Barcelona, December 2012 


\section{Institut Català Internacional per la Pau}

Gran Via de les Corts Catalanes 658, baixos · o8010 Barcelona

T. +34935544270 | F. +34935544280

recerca.icip@gencat.cat|http://www.icip.cat

\section{Editors}

Javier Alcalde and Rafael Grasa

\section{Editorial Board}

Pablo Aguiar, Laia Balcells, Alfons Barceló, Gema Collantes-Celador, Caterina Garcia, Abel Escribà, Tica Font, Antoni Pigrau, Xavier Pons, Alejandro Pozo, Mònica Sabata, Jaume Saura, Josep Maria Terricabras and Léonie Van Tongeren

\section{Typesseting and printing}

Ātona, S.L. / gama, sl

\section{ISSN}

2013-5793 (online edition)

2013-5785 (paper edition)

\section{DL}

B-34.513-2012

\section{co80




\section{THE AUTHOR}

Regina Salanova is Project Manager at the United Nations University Institute in Barcelona. She received her Master's degree in International Affairs from Columbia University in 2009. She holds a BA in Journalism by the Autonomous University of Barcelona and has worked as a reporter for the Spanish media from 1999 to 2007 in Barcelona and Brussels. Before joining UNU, she was programme analyst at UNDP, working on development projects in Latin America and the Caribbean. Her research interests are on media and conflict resolution, peace building and cross-cultural communication. This paper is the first research work of her doctoral thesis at the Autonomous University of Barcelona.

\section{ABSTRACT}

Throughout the past decade, social media have come on the scene of various popular revolts. Their role as tools of information and coordination of social movements, from the Iranian Green Movement in 2009 to the Arab uprisings in 2011, has been widely debated. In most cases, online activism through blogs, Facebook, Twitter or other forms of social media has allowed citizens to be part of a social networking exercise and to engage in a public sphere that would have otherwise been unreachable to them due to severe repression. In Tunisia and Egypt, social media helped protests start and expand thanks to their ability to coordinate and disseminate information quickly. The new information and communication tools were an influential factor in accelerating the revolutionary processes across the Arab world, albeit they cannot be seen as neither the spur nor the drivers of any revolution.

Keywords: Arab uprising, 2010; Egypt-History, 2011, Revolution; TunisiaHistory, 2011, Revolution 


\section{RESUM}

Durant la darrera dècada, les xarxes socials han arribat a diverses revoltes populars. El seu paper com a instruments d'informació i coordinació dels moviments socials, des del Moviment Verd d'Iran el 2009 fins a les revoltes àrabs el 2011, ha estat àmpliament debatut. En la majoria dels casos, l'activisme en línia a través de blocs, Facebook, Twitter o altres formes de comunicació social ha permès als ciutadans formar part d'un exercici de creació i de participació en una esfera pública que d'una altra manera hagués estat impossible a causa de la repressió. A Tunísia i a Egipte, les xarxes socials van ajudar a iniciar i ampliar protestes, gràcies a la seva capacitat per coordinar i difondre informació ràpidament. Les noves eines d'informació i comunicació han estat un factor influent en l'acceleració dels processos revolucionaris a tot el món àrab, tot i que no es pot considerar que siguin l'incentiu de cap revolució.

Paraules clau: Primavera àrab, 2010; Egipte-Història, 2011, Revolució;

Tunísia-Història, 2011, Revolució

\section{RESUMEN}

Durante la última década, las redes sociales han llegado a varias revueltas populares. Su papel como instrumentos de información y coordinación de los movimientos sociales, desde el Movimiento Verde de Irán en 2009 hasta las revueltas árabes en 2011, ha sido ampliamente debatido. En la mayoría de los casos, el activismo en línea a través de blogs, Facebook, Twitter u otras formas de comunicación social ha permitido a los ciudadanos formar parte de un ejercicio de creación y de participación en una esfera pública que de otra manera hubiera sido imposible debido a la represión. En Túnez y en Egipto, las redes sociales ayudaron a iniciar y ampliar protestas, gracias a su capacidad para coordinar y difundir información rápidamente. Las nuevas herramientas de información y comunicación han sido un factor influyente en la aceleración de los procesos revolucionarios en todo el mundo árabe, aunque no se pueden considerar incentivos de ninguna revolución.

Palabras clave: Primavera árabe, 2010; Egipto-Historia, 2011, Revolución; Túnez-Historia, 2011, Revolución 
$\begin{array}{ll}\text { 1. INTRODUCTION } & 7\end{array}$

2. SOCIAL MEDIA AND SOCIOPOLITICAL CHANGE 9

2.1. THE EMERGENCE OF SOCIAL MEDIA IN PUBLIC AFFAIRS 9

2.2. THE ROLE OF SOCIAL MEDIA AS AN INSTRUMENT

FOR POLITICAL STRUGGLE

2.3. THE AMBIVALENCE OF SOCIAL MEDIA: DANGERS

AND OPPORTUNITIES

3. THE USE OF SOCIAL MEDIA IN THE ARAB UPRISINGS:

A DEBATE IN PROGRESS

3.1. OVERVIEW OF THE EVENTS

3.2. ARAB MEDIA AND THE NEW PUBLIC SPHERE

3.3. THE ROLE OF SOCIAL MEDIA IN THE ARAB UPRISINGS:

AN OPEN DEBATE

28

3.4. AN ANALYTICAL FRAMEWORK

4. CASE STUDY: THE 2011 TUNISIAN AND EGYPTIAN REVOLUTIONS

4.1. INTERNET AND SOCIAL MEDIA USAGE

4.2. SOCIAL MEDIA AND GRASSROOTS MOVEMENTS BEFORE THE REVOLUTIONS

4.3. A TOOL DURING THE UPRISINGS

4.4. THE ROLE OF MAINSTREAM MEDIA: COMPLEMENTARITY OR DEPENDENCE?

4.5. STATE CONTROL THROUGH SOCIAL MEDIA: FROM BLACKOUTS TO CYBER WAR

5. CONCLUSIONS

6. LIST OF REFERENCES 



\section{INTRODUCTION}

Over the past decade, a debate has emerged how social media influence social movements and political change. The Arab uprisings of $2011^{2}$ certainly revived this debate among supporters and detractors of the power of these new media tools as a way of communication, used and misused by both activists and state powers. In Tunisia, hundreds of tireless young cyber activists had been challenging the authoritarian regime's censorship through countless blogs and other forms of online communication, developing into a latent force that eventually led to a street mass mobilization and the fleeing, on 14 January 2011, of President Zine El Abidine Ben Ali. In Egypt, the youth closely followed the Tunisian way and quickly engaged their efforts in establishing strong online social networks that would ignite massive protests and, ultimately, drive President Hosni Mubarak from power on 11 February 2011.

In a globalized era, the use of Internet and the new information and communication technologies has undoubtedly changed the dynamics of social movements and political change. The Arab world has been no exception; there, the new media environment has reshaped the nature of politics and, especially, it has challenged the way authoritarian regimes operate. On the one hand, the rapid proliferation of Arab satellite television and new internet-based media have urged Arab regimes to change the way they perceive and make use of media as a way of state control over public opinion. On the other hand, new media tools such as Facebook, Twitter or YouTube have influenced not only the

1. The author is affiliated to the United Nations University in Barcelona. Please send your comments and questions to the following e-mail address: salanova@unu.edu.

2. Throughout the paper, I have deliberately referred to these events as the Arab uprisings, Arab revolts, or Arab revolutions, trying to avoid the so-called Arab Spring approach as much as possible. This position is argued by the fact that neither the temporality nor the geographic extension of the events quite actually fit into the Arab Spring concept. Moreover, I have tried to stick to the descriptor collective-nouns that the actors of these events have been using to refer to their collective action, most commonly in their Arabic terms: al-thawra (revolution or uprising), as-sahwa (awakening) or ennahda (renaissance). 
way the Arab public sphere is being rethought, but also the way the Arab community is perceived internationally.

This paper argues that, while social media can have a prominent role in the coordination and mobilization of grassroots movements and be a useful tool in forging political change, they are neither the actors nor the drivers of a revolution. Additionally, it gives evidence of how new media tools are a double-edged sword that can be used either for overcoming authoritarian regimes or political manipulation. It discusses the need for framing social media within a broader context of media power, in order to better evaluate its effects on the public opinion and public affairs. Finally, it also argues that the level of impact social media can have on collective action may vary depending on the socio-political context of a given country, and that they may not always have the power needed for shaping new democracies.

In order to support this hypothesis, this paper examines the following main research questions:

1. What characterizes the dynamics between social media, grassroots movements and authoritarian regimes?

2. How does this dynamic influence political change?

With the purpose of narrowing the scope of the analysis, the study focuses on smaller questions so as to explain how the new information scene has influenced both Arab politics and the most recent changes sweeping the Arab region:

i. How have social movements engaged with social media?

ii. How have social media challenged Arab states?

iii. To which extent have new social networking tools contributed in reshaping Arab politics from within and at an international level?

iv. What are the mechanisms that have allowed new and old media to influence the public agenda in the Arab world?

To answer these questions, I have organized the paper into sections. Section two presents an overview of the main features of the relationship between social media and politics, aiming at providing a conceptual framework for the analysis. In the third section, I provide the context in which the protests have evolved across the Arab region and I explain the academic debate that has been generated about the rele- 
vance of social media in the uprisings of 2011. In the fourth section, I examine the role and effects of social media in the Tunisian and Egyptian uprisings in connection with the framework described in the first section. This case study looks at data on both countries' social media penetration and grassroots movements in the light of the outcomes of their respective revolts. This enables identification first of the elements that might help explain the relationship between social media and political change and second of remarkable traits of new media tools that may have influenced the events. Attention is drawn, on the one hand, to the bidirectional influence between new and old media and, on the other hand, to the control exerted by authoritarian regimes. Finally, I conclude this paper discussing the need for a better understanding of the role of social media in political change and the importance of conducting further research on this subject.

\section{SOCIAL MEDIA AND SOCIOPOLITICAL CHANGE}

In this section, social media are presented as communication tools in sociopolitical contexts. It explains the role of the new information and communication technologies (ICT) in public affairs, in policy-making; and in sociopolitical movements. Finally, this section reflects both the favorable and the unfavorable consequences of the use of social media as a tool for politics.

\subsection{THE EMERGENCE OF SOCIAL MEDIA IN PUBLIC AFFAIRS}

The rise of digital technologies that make social media possible has revolutionized the way civil society and institutions communicate opinions and disseminate information. Social media have allowed for a faster and less costly way of transmitting information among individuals, communities and organizations in a globalized era. The new 
global public sphere, as argued by Castells (2008), is built around the media communications system and Internet networks: web-based technologies such as blogs, social networks (Facebook or Twitter) or social spaces filled with user-generated content (YouTube) are representations of the new technological means by which civil society can exist independently from political institutions and from mass media.

Social media have become platforms from where ordinary people are able to influence public affairs (Auer 2011). New information and communication technologies have allowed citizens to take part in any of the stages of the communication process: they can create the content of a news item, they can disseminate it, and they can consume from a broad range of sources. Moreover, they have speeded up the course of communication.

One of the main elements that need to be addressed when analyzing the impact of social media on social movements is their role in the agenda setting, a power historically in hands of the traditional media. Agenda-setting theory explains how audiences can perceive a given news item depending on the significance that media give to the news story - in terms of the coverage and position (McCombs and Shaw 1972). With the ascendance of digital media, audiences are open to consume news from wide variety of sources, which allows for a higher degree of freedom in the selection of news, thus avoiding the traditional one-way imposure of what media believes needs to be set on the public agenda. In this way, the agenda-setting function may have been altered, either by diminishing the ability of mainstream media to set the political agenda or by reversing the flow of information (Sayre et al. 2010).

\subsection{THE ROLE OF SOCIAL MEDIA AS AN INSTRUMENT FOR POLITICAL STRUGGLE}

The use of social media tools as a means to raise awareness and mobilize the masses against the status quo of a given country or regime is certainly not new. Social and political activism has had very significant episodes throughout the twentieth century, from non-violent civ- 
il disobedience in India to civil right movements in the US among many others, yet social media have given social movements useful tools to coordinate and to undertake collective action. Clay Shirky's analysis on the power of social media in enhancing democracies is probably one of the best attempts at glorifying social media movements (Shirky 2011). Shirky believes that social media have a key role in echoing public opinion. To him, access to conversation is far more important than access to information. In the long run, he argues, social media may help increase freedoms as the printing press, postal service or the telegraph did before.

Internet has benefited grassroots movements by providing new possibilities for citizens to organize even under authoritarian regimes. As Yochai Benkler argues, with the inclusion of Internet in the framework of social mobilization, there has been a qualitative change "represented in the experience of being a potential speaker, as opposed to simply a listener" (Benkler 2006). According to him, Internet has not only reduced the cost of producing and publishing media content but it has also decentralized media production, making it much harder for authoritarian regimes to control and censor media outlets.

Nevertheless, there are many detractors of this uncontested role of social media. Malcom Gladwell, whose criticism of online activism became clear in his article Why the revolution will not be twitted, disregards of the role of social networking in effecting social and political change ${ }^{3}$. Social networks, he claims, have encouraged an easy activism whereby action has a lower impact. His critics are crystal clear: "Facebook activism succeeds not by motivating people to make a real sacrifice but by motivating them to do the things that people do when they are not motivated enough to make a real sacrifice". Gladwell's argument is also supported by Paul Mason (2012), who agrees with the fact that networks allow people to assemble and protest against a target, but he believes that the commitment levels are much limited. Social

3. Gladwell draws his criticism by accounting some of the most outstanding social movements of the twentieth century. He argues that they happened "without e-mail, texting, Facebook, or Twitter". See Gladwell, Malcolm. "Small Change: Why the Revolution Will Not be Tweeted”, in The New Yorker, October 4, 2010 
media have played a big role overcoming official censorship and propaganda, he says, but the revolutions in the Arab world "have been social, political and real - not virtual”.

In any case, recent history gives us a few examples of how social networks operated in order to benefit activists seeking to expand their efforts, communicate their ideas or make information available in places where traditional communication tools were limited or not even allowed. In authoritarian regimes, different forms of social media can provide alternative sources of news and information (Etling et al. 2010). Facebook and Twitter are today among the most commonly known due to the recent events in the Arab world, but cell-phones' text-messaging, video-recording or blogging have been very active in the past decade. New technology tools have strengthened the power of citizens who, often more quickly than professional journalists themselves, can report news as they happen. Some argue that citizen journalism can be extremely useful in contexts of oppression or state control over mainstream media. According to Khamis, Gold and Vaughn (2012), citizen journalists "can function as a proxy free press, a medium that can uncover and challenge falsehoods and misinformation".

In 2001, cell phones were central in organizing a massive protest against the government's corruption in the Philippines ${ }^{4}$. Texting messages reading "Go 2 EDSA" 5 was an effective strategy to rapidly convey thousands of angry citizens in one of the major crossroads in Manila, who wanted to raise their voice against an impeachment trial that would have otherwise left President Joseph Estrada free from responsibility. The protests, commonly known as People Power II, allowed information on the President's corruption to be shared widely. The results came immediately: Estrada resigned only three days after the protests. As Filipino TV journalist David Celdran writes, SMS had become one of the most popular forms of communication in the Philippines, making them a "potential tool for mediating political informa-

4. See http://www.washingtonpost.com/wp-dyn/content/article/2006/o8/24/AR2006o 82401379.html (Accessed August 16, 2012)

5. EDSA stands for Epifanio de los Santos Avenue, where the over a million protesters gathered during the following days. 
tion and accelerating the process of political change"6. Nevertheless, some studies have shown that there might be no significant relationship between mobile usage and anti-government protests7 .

There are, however, other examples of new media activism not achieving any political shift, although the use of new information and communication technologies did have an impact in the coordination of protests. The 2007 Myanmar protests, for instance, fueled by rising gas prices and the country's worsening economic situation, are known for having used multiple forms of social networking for both organizing the demonstrations and communicating the unfolding events live. The country, had long been ruled by a military regime, did not leave space for open and free media and protesters turned to the Internet in search for ways to inform about the situation. The protests caught global attention as citizens secretly filled the cyberspace with images and videos of monks leading large, peaceful demonstrations against the government (Chowdhury 2008). Information about events in Myanmar was rapidly disseminated through the mainstream media and thanks to the use of new information technologies, which had an exponential effect in communicating the events internationally. Even international media accentuated the role that modern communication technologies were having not only in informing about government abuses but also in challenging a repressing regime ${ }^{8}$. Many blogs served not only to transmit information but also to collect news from different sources ${ }^{9}$. Social networking sites also played an important role in

6. Celdran's reflections on the role of text messaging in the Philippines are argued in his article Philippines: SMS and citizenship, available at: http://www.dhf.uu.se/pdffiler/o2_01/o2_1_part9.pdf (Accessed on August 15, 2012)

7. For an extensive analysis of how mobile communication relates to political change, see Miard, Fabien. Call for Power. Mobile phones as facilitators of political activism. Universitetet I Oslo, November 2008. In his strudy, Miard concludes that "mobile connectivity can neither negatively, nor positively be associated with political activism".

8. Examples of coverage of both the events and the way mainstream media referred to the importance of social media tools, can be seen at: http://www.nytimes.com/2007/09/24/ world/asia/24myanmar.html?_r=1\&pagewanted=all; http://thelede.blogs.nytimes.com/ 2007/09/28/burmese-government-clamps-down-on-internet/; and http://edition.cnn. com/2007/WORLD/asiapcf/o9/28/myanmar.dissidents/ (Accessed August 16, 2012)

9. There were many sites illustrating the resources available during the protests. Among others, the following had a relevant impact during the events: the Burmese Bloggers 
engaging people to the cause ${ }^{10}$. While it is difficult to prove a direct causal impact, the awareness and attention created by online activists helped shape international attention and action towards addressing the Myanmar crisis. However, as the protests resulted in a brutal military crush, it is difficult to conclude that the use of social media lead to any tangible political change (Chowdhury 2008).

The debate over whether social media indeed has a direct effect on revolutionary process had a turning point during the 2009 Iranian protests. Following President Mahmoud Ahmadinejad's disputed reelection, protests spread across major cities in Iran in what was called the Green Revolution - it was reflecting the campaign color of the opposition candidate Mousavi. The international media quickly supported one argument or the other ${ }^{11}$. But as the movement lost momentum, so did the theory of the Twitter Revolution, which for some was no more than a Western fantasy ${ }^{12}$. No significant political change was achieved; after the protests, the Islamic Revolutionary Guards Corps established a cyber-defense command to counter online political activism, making Twitter and Facebook inaccessible to those without filter proxies acquired in the West (Abdo 2011). In this regard, social media during the Iranian protests of 2009 is seen only as a tool for reporting the events as they unfolded and nurturing the international press with live tweets from Teheran and videos documenting the pro-

without borders (http://bbwob.blogspot.com.es/) and the Democratic Voice of Burma (http://english.dvb.no/).

10. The best example may be that of Facebook. Many groups were set up to support the people of Myanmar, such as the "Support the Monk's Protest in Burma” (http://www.facebook.com/BurmaGlobalActionNetwork)

11. The New York Times published an editorial on 16 June 2009 in which it claims the importance of social media such as Twitter or YouTube in reporting the events. Accessed August 16, 2012: http://www.washingtontimes.com/news/2009/jun/16/irans-twitterrevolution/. Time Magazine also backed up this thesis on June 17, 2001. Accessed August 16, 2012: http://www.time.com/time/world/article/o,8599,1905125,00.html. On the contrary, the Washington Post opted to publish an article just a few days after in which it asserts that the revolution was rather on the streets. Accessed August 16, 2012: http://www.washingtonpost.com/wp-dyn/content/article/2009/06/19/AR200906 1901598.html

12. Evgeny Morozov is one of the leading critics of the expression "Twitter Revolution" when it comes to political change movements. 
tests. As it had happened in Myanmar, there is some evidence that indicates that the greatest amount of tweets about the Iranian protests occurred mainly in the West and it is not proved that they had a causal effect in organizing them (Etling et al. 2010).

\subsection{THE AMBIVALENCE OF SOCIAL MEDIA: DANGERS AND OPPORTUNITIES}

The use of social media and its effect has many interpretations and it all depends on the context where it is being applied. The potential impact and limitations of social media on political change make new digital applications a powerful tool to those who consciously decide to make use of them. It has vastly been argued that new media tools help social movements in organizing and disseminating information, as seen above. However, much has also been argued about the perverse effects of the social media. Evgeny Morozov may well be one of the leading pioneers of this wave of thought, clearly arguing that technological advance does not translate into democratic transformation. His skepticism is well depicted in his masterpiece "The Net Delusion", in which he holds the argument that social media -Internet, in general- can be as effective in helping political activists achieve their demands as powerful in backing up authoritarian regimes (Morozov 2011). This critique of social media is based on the hypothesis that authoritarian regimes can be as quick as activists in using new media tools for their own interest, as a means of monitoring and controlling societies with increasingly improved mechanisms. Recent studies and extensive evidence also indicate that Internet control mechanisms have improved and that more governments use more sophisticated methods to filter and monitor web-based contents, like targeting local languages and websites of opposition movements (Deibert 2009).

As it happens with mainstream media, social media can be a double-edged sword; their use by political activists or by state actors can lead to totally opposite outcomes. It is what Kyriakopoulou (2011) calls the "dyadic nature of social media": on the one hand, they can be a tool for opening up to democracy and challenge authoritarian states. 
They can become a source of useful information, raising awareness that enable the emergence of social capital. On the other hand, social media can support authoritarian states in their efforts of disseminating propaganda.

Some authors have pointed out a major weakness of social media: when used by leaderless movements, they may experience frustration when the time comes for negotiating, as these movements do not have the usual array of party elites. When the time arrives for dealing with the terms of democratic transition, online activists cannot defend their demands, as they do not have a visible leader to participate in the negotiations (Lynch 2011).

On the other hand, social media pose another danger yet to be thoughtfully analyzed. New information and communication technologies are basically designed to be open and unlimited in that the length, amount or even the accuracy of what is being transmitted through social media can sometimes lead to misinformation. In this regard, social media's strengths can also create problems, as discussed in Matthew Auer's (2011) analysis on social media. According to Auer, the challenge then is "sorting critical information from junk on social networks" until they gain reputation.

Social media though can also bring opportunities beyond their role in accelerating social movements by providing upgraded forms of communication. Authoritarian regimes can indeed learn fast and adapt to new tools and strategies. They can even shut down the Internet as it happened in Burma and Iran but, in doing so, they may have to face economic and political consequences and, what is more, opposition movements may grow more legitimated for their cause. As Bruce Etling, Robert Faris and John Palfrey put it, "Internet may be the only avenue left for citizens in authoritarian regimes to influence government, fight corruption or defend their rights" (Etling et al. 2010). 


\section{THE USE OF SOCIAL MEDIA IN THE ARAB UPRISINGS: A DEBATE IN PROGRESS}

This section provides an overview of the context in which the Arab uprisings of 2011 occurred. It first gives a brief account of the events. Then it presents the Arab media environment - old and new- from a historical perspective and its relevance to the Arab public sphere. It also explains the current scholarly debate on the role of social media in the revolts. It finally proposes an analytical framework to collect and organize the data of the case study developed in the following section.

\subsection{OVERVIEW OF THE EVENTS}

The unexpected democratic uprising that started in Tunisia beginning of 2011 rapidly extended to most of the Arab countries. These social protests set off a chain of unprecedented events that are still having deep effects all across the region. The outcomes and real impact of these social revolts are still not certain and will need to be accurately addressed and interpreted in historical perspective, in view of the current situation ${ }^{13}$. Nevertheless, there are already many elements that can be considered for analysis in light of the events that have occurred in 2011 and part of 2012 across the Arab region.

On 17 December 2010, a young street vendor of the central Tunisian city of Sidi Bouzid set himself on fire in protest of the humiliation and harassment received from a municipal officer after the confiscation of his wares. Tarek al-Tayeb Mohamed Bouazizi's self-immolation induced the first protests of what ended up being known as the Tunisian Revolution. This fact, albeit symbolically decisive, was just the last straw after long years of repression and torture carried out by Ben

13. At the time of writing this paper, protests, civil disorders and civil wars such as the ongoing internal armed conflict in Syria continue to make the region refrain from stabilizing. 
Ali's authoritarian regime. Likewise, a wave of unrest spread all over the Arab region soon after the Tunisian case: it first hit Algeria with major protests starting on 28 December 2011, and then it continued in Jordan, Egypt, Yemen, Iraq, Bahrain, Libya, Kuwait, Morocco and Syria, where protests led to either a change of government or some political reforms. To a lesser extent, other countries such as Mauritania, Oman, Saudi Arabia, Sudan or Lebanon have also experienced protests as a result of the revolts that have shaken the region in the past year.

As a result, governments in four Arab countries have been overthrown. Tunisian President Ben Ali fled to Saudi Arabia on 14 January 2011. Egyptian President Hosni Mubarak resigned on 11 February 2011, only 18 days after the start of the protests. In Libya, Muammar Gaddafi was deposed on 23 August 2011 and later killed on 20 October 2011 after the National Transitional Council (NTC) took control of his hometown Sirte. Finally, in Yemen, a presidential election was held and President Ali Abdullah Saleh ceded power to Abd Rabbuh Mansur Al-Hadi on 27 February 2012. In other parts of the regions, the wave of uprisings has forced many leaders to reform their country's constitutions, as it happened in Morocco, or to announce that they would not seek reelection, as it was the case Iraqi Prime Minister Nouri al-Maliki.

\subsection{ARAB MEDIA AND THE NEW PUBLIC SPHERE}

Following their independence, Arab states went through a series of modernization processes that brought them toward sovereignty. They would focus on elements of national identities and cultural differences, in order to create national loyalties and, to some extent, to create unity within the newly established independence of the nation-state. State authorities used the media industry as a platform to propagate the Arab unity approach, making use of the public sphere ${ }^{14}$ to shape

14. In 1962, German sociologist Jürgen Habermas already theorized about the important role media plays in keeping the public sphere as a counter power tool. In his first major work The Structural Transformation of the Public Sphere, Habermas describes the way 
public opinion to their own convenience (Ayish 2011; Lynch 2011; and Mellor 2011). Films, radio stations and music production, among other means of mass communication, were used to promote state policies. Pan-Arab media outlets included radio stations and newspapers $^{15}$, but it was television broadcasting what had the main role in shaping this new identity of global community. The use of new information and communication technologies came as a challenge to the previously existing media system, creating a totally new media environment (Kraidy 2002 and Rinnawi 2006).

After the 1991 Gulf war, the Arab media industry experienced a deep reform with the launch of many state-owned satellite channels and the opening of a totally new market for privately managed media. The rise of these new policies of proliferation of media outlets was mainly due to the emergence of a new generation of Arab politicians willing to modernize their media institutions (Mellor 2011). Simultaneously, the raise and influence of Western-driven media channels such as $\mathrm{CNN}$ or $\mathrm{BBC}$ - especially when they launched their Arabic versions ${ }^{16}$ - made Arab states respond by boosting their own global Arab broadcasting systems and many satellite TV channels rapidly developed and gained popularity all over the region ${ }^{17}$. The peak of this process, however, was

the press is transformed from being private to being a public domain, the "public sphere's preeminent institution". The public sphere is a concept arisen in the nineteenth century to describe the areas were private people would meet to freely discuss public affairs in order to influence political authorities. These discussions would happen in coffeehouses, public squares, private salons of the elites' residences, and in the media. Habermas saw the public sphere, and especially that of the media, as a major instrument to exert control over authorities.

15. The first pan-Arab media outlet was the Cairo-based radio station Sawt al-'Arab (Voice of the Arabs), which was very well welcomed by a wide audience during the 1950 s and 1960s. It was followed by the creation of daily satellite newspapers such as al-Sharq alAwsat (The Middle East), al-Quds al-'Arbi (Arab Jerusalem) and al-Hayat (Life), which were physically located outside the Arab world, thus avoiding common censorship practices.

16. In 2002, CNN launched an Arabic website, located in Dubai, which offers updates on regional and international developments: http://arabic.cnn.com/. The BBC launched its Arabic channel in 2005. Accessed July 27, 2012: http://articles.cnn. com/2005-10-25/world/bbc.arabic_1_bbc-world-tv-arabic-tv-language-services?_ $\mathrm{s}=\mathrm{PM}:$ WORLD

17. The Egyptian Satellite Channel made the first satellite broadcasting transmission on 1990. It was followed, just one year after, by Saudi Arabian's Middle East Broadcasting 
achieved when the first Arab all-news satellite channels appeared on the scene. Qatar-based Al-Jazeera was launched in October 1996, altering the Saudis monopoly on Pan-Arab media. Al-Jazeera could be seen as part of Qatar's Emir strategic plan to challenge Saudi Arabian primacy in the Gulf (Rinnawi 2006). It has been argued that Al-Jazeera dominated the Arab public discourse until 2002, when other stations like Al-Arabiya, a Dubai-based network mostly funded by Saudi Arabia ${ }^{18}$, emerged to challenge its leadership in the all-news share (Lynch 2011). Some others add to that that Al-Jazeera created a somehow new space for critical discourse about Arab politics (Nelson 2008), putting in constant tension many Arab governments and Qatar's rulers (Kraidy 2002). The only topic that the Arab all-news leading station can leave untouched is internal Qatari politics (Rinnawi 2006).

The effects of this booming of the new Arab media on the Arab society have been greatly discussed. According to Benedict Anderson (2006), Arab transnational media have had an important role in today's re-imagination of the Arab community ${ }^{19}$, thus regaining the

Center (MBC), which was privately owned by Saudi royal family members. The list of Arab satellite TV stations is long and has in the recent decades shaped not only the media scope of the region, but also the numbers of satellite penetration in the Arab world. Nevertheless, main players in this scene (MBC, ART, Orbit TV, al-Jazeera, LBCI, ANN, Nile TV, al-Manar, among others) can be classified by ownership, location and contents. Many authors have analyzed their contents and impact (Rinnawi 2006, Mellor et al. 2011).

18. Although being supported by Saudi Arabian money, Al-Arabiya is based in Dubai Media City, United Arab Emirates. As Al-Jazeera's primary rival, it mostly portrays the U.S. and Saudi Arabia in a more favorable perspective (Nelson 2008).

19. Taking Anderson's concept of the imagined community as a framework in which Arab media serves as platform for the transmission of collective consciousness, we can distinguish a new form of regionalism with direct effects over Arab media. Khalil Rinnawi (2006) calls this regionalization process McArabism, described as the result of the interaction between new (globalized) media technologies and local (tribal) trends and powers. Broadcasting in McArabism terms means working on different levels of communication to create sociocultural content, including news bulletins focusing on shared political issues, Arab and Islamic programs aiming at educating the audiences and entertainment programs with special products targeting children. Contents tend to be emotive and are broadcasted under what Rinnawi calls "direct engagement", using many different tools to allow audiences understand the news in a clearer and effortless manner. It is important to highlight that Arab transnational television uses Modern 
value of the lost public sphere, much like the role the newspaper had in creating an imagined community of European nations in the 18th century as described by Jürgen Habermas in 1962. In his work on the contribution that the media revolution is making to the emergence of a new Arab consciousness, Lawrence Pintak (2009) also underlines that pan-Arab satellite TV stations have been able to blur the lines between Arab states in the imagination of the Arab people. He stresses the importance of the role played by communication professionals who perform under this umbrella. Following a comparison of data from a survey of Arab journalists, Pintak argues that they are real active actors of the construction of this "emerging 'imagined' watan [nation]". Mark Lynch (2006) believes that the emergence of these satellite television networks, which prioritized politics and a region wide public discourse, was necessary to create a new Arab public sphere. Yet others argue that the appearance and evolution of the satellite Arab media industry, despite its importance and its efforts to offer new programming, has not developed into a fourth power nor it has any maneuver towards encouraging civil society or democracy (Rinnawi 2006). According to this view, pan-Arab media have mostly played domestic politics, while fostering a collective socio-cultural imaginary.

State control over the media has been continuous and evident in the Arab world, although traditional media regulations vary from country to country. There are common patterns to control the flow of information and the public discourse. As political scientist and Arab media expert, Mark Lynch (2006), declares, censorship "closed down most public avenues of political debate" and reduced the public spheres described above to a non-existing entity that would remain in people imaginary. The press and broadcast media were directly controlled by the leading elites and had no space for political opposition.

Standard Arabic to broadcast news and other programs. It is indeed one of the major contrasts to the pre-satellite period, when the majority of state-owned TV stations used local dialects. Being able to communicate in one single form of Arabic makes transnational broadcasting a better tool to achieve the so-called McArabism. 
State officials have strictly controlled broadcasting media in the Arab world, which almost exclusively served Arab regimes' self-interests. Constantly programming time devoted to political information and propaganda, state intervention was done through censorship, self-censorship, the use of emergency laws and other ways of pressure (Rinnawi 2006). During the 60 years period that preceded the satellite era (1920s-1980s), television and radio systems in the Arab world -what Khalil Rinnawi calls tribal broadcasting system- were literally in the hands of and manipulated by state leaders who deliberately attempted not only to maintain socio-cultural order and cultural religious values, but also to prevent external messages to interfere into their business.

Notwithstanding its severe application, Arab regimes' censorship has not always gone in line with post-independence constitutions, which paradoxically give high importance to freedom of speech. This has made most of the Arab countries to eventually pass and enforce laws that regulate media, usually diminishing free speech (Mellor 2011). Emergency laws, like in the case of Egypt or Syria, and other laws granting governments to prosecute journalists, like in Jordan or Bahrain, normally end up encouraging self-censorship. Orayb Aref Najjar (2008) describes some of these restrictive regulations to constrain the media in a comparative analysis between Egypt and Jordan. The analysis reveals that, albeit the instability that these countries have faced over time (as regards terrorism, for example), they have always followed a certain path in the way they regulate the media, especially by directing laws at curbing the enemies and critics of the states' regimes. Enclosing media regulations within these somehow liberal constitutional frameworks has led to a "large degree of informal and indirect censorship" (Rinnawi 2006).

Although the Arab media scene and its influence over public opinion and policymaking is very well represented by the broadcasting system (as seen in the previous section), attention should also be paid to the development and role of the print media in the Arab region. Nabil Dajani (2011) argues that, beyond the role of the state, the regulation of the Arab press "is influenced by sociopolitical and geopolitical fac- 
tors contributing to the materialization of the modern Arab states"20. In most cases, as described by Dajani, the Arab press has been directly or indirectly influenced by two main elements: colonization and postindependence. Egypt, for instance, had enjoyed a significant press freedom up until the 1950s, when the new regime brought about government regulations for the reasons already explained above. The effects of this nationalization of the Egyptian press persisted from Nasser, to Sadat and Mubarak, the latter introducing a slightly more flexible press law only in 2006, although it still allowed some forms of censorship. In the case of Tunisia, its press industry greatly follows a French style in the way newspapers are editorialized. Nevertheless, open criticism of the state's authorities is restricted due to harassment and repression. It is worth highlighting too that Tunisian press has usually targeted the elite.

In terms of regulating the transnational Arab satellite broadcasting, Arab regimes have faced a higher degree of challenge. Rinnawi (2006) goes even further and describes it as "the largest and most pervasive media challenge in contemporary history to state regime dominance". May this challenge be geographic, economic or technologic, it has pushed states to create alternative state-sponsored television and to apply specific measures to limit transnational media to enter each country. Examples of these measures were seen in Egypt, were policies against ownership of satellite equipment or cable access were enforced in order to avoid certain radio and television transmissions, and in Tunisia, were a law was passed in 1995 enforcing a licensing regime, although authorities had tried to ban the import and installation of satellite dishes in the early 1990s (Rinnawi 2006). As regards ownership, regimes have opted for either direct state-control or indirect ownership through the ruling elite.

While the above is true for many of the Arab countries' internal dynamics, the rise of satellite television systems has indeed posed real obstacles to state control by reducing government's capabilities to use

20. In his work on the changing roles of Arab print press from the nineteenth to the twentyfirst century, Nabil Dajani draws on the fact that popular Arab press developed because of conflict, during times of major social and political events in the region. 
their censorship's tools. Carola Richter (2008) explains how internal pressure from private investors and business lobby groups in most of the Arab world has ultimately resulted in a "guided deregulation of the media sector, opening up spaces for non-regime actors" ${ }^{21}$. This has made Arab authorities to somehow modify their media regulations in order to allow commercial interests through independent television channels, such as Dream TV in Egypt (Rinnawi 2006). Moreover, the extraordinary amount of revenues that the media business is providing to the investors - this is especially certain in terms of broadcast media- is driving some states to launch the so-called free media zones to encourage more investments. This has been the case mainly in the Gulf countries, although Egypt has also promoted its own media city. The case of Tunisia is significantly different. Although the Tunisian Constitution grants press freedom, there was an absolute control over the media and criticism of the state's officials was highly discouraged (Dajani 2011 and Filiu 2011). Tunisian audiovisual media had traditionally been under surveillance of the Établissement de la Radiodiffusion-Télévision Tunisienne (ERTT), which would oversee both television and radio broadcasting since 1957. The state would have the monopoly on domestic television services and only a very small number of radio stations were in private hands. The Tunisian audiovisual scene included a private TV channel only in 2005, when Hannibal TV was launched via satellite and terrestrially. Not surprisingly then more than half of the TV audiences in Tunisia are connected via satellite channels daily, looking for uncensored information ${ }^{22}$.

During the 1990s, while the satellite media industry was experiencing its mushrooming momentum, the Arab countries faced another revolutionary technological development that had a strong impact on the region. Internet entered the homes of the Arab world during the

21. Richter conducted a very relevant study on how new Islamist media strategies have had a direct effect on Arab media and politics. Among other findings, the author underlines the importance of softening the media regulations across the Arab countries in giving voice to new actors in national and transnational politics.

22. Accessed August 30, 2012: http://www.aljazeera.com/indepth/opinion/2011/o1/201111 6142317498666.html 
1990 s and some argue that it has even created a new generation of pan-Arabists (Rinnawi 2011). Internet was for the first time linked in an Arab country in 1991, in Tunisia, although it was not until 1996 that it became widely used. Interestingly, Egypt came after in 1993, like Algeria and the United Arab Emirates. The rest of the Arab states followed their precursors during the next decade. For the purpose of this paper, it is important to underline that Arab states made huge efforts in making internet available to their citizens from the very beginning, as a means of economic development for their counties. Consequently, Internet penetration in the Arab world rapidly spread across the region: by December 2011, there were over eighty million users of Internet in the Arab world ${ }^{23}$. Internet usage in the region, which represented $24 \%$ of the total Arab population, was thirty times higher 2011 than in the year 2000, as seen in Figure 1. Although it may seem to be a relatively low percentage of users, it is not so far from the world's total Internet penetration (32.7\% by December 2011). Nevertheless, as Khalil Rinnawi (2011) points out, there have always been many obstacles to Internet diffusion. Governing elites have been very cautious in keeping some formal and informal regulation in order to prevent from having any type of challenge to their rule. Yet other aspects, as Rinnawi suggests, have also put some barriers to the good development of the Internet as a tool for free speech in the Arab world, such as high rates of illiteracy, language barriers or lack of infrastructure.

In any case, and in spite of all the attempts by the Arab regimes to control the usage and contents, Internet succeeded in somehow becoming a new and alternative form of public sphere, widely used by those who had traditionally been marginalized in the mainstream and state-controlled media. As it happened with satellite television, Internet posed even further difficulties to state powers to exert censorship. It suddenly became one of the most used instruments for civil engagement in the public life of Arab societies. Rinnawi (2011) explains in

23 Data extracted from the Internet World Stats (available at www.internetworldstats.com - Accessed on 26 August 2012). Copyright (C) 2012, Miniwatts Marketing Group. Population numbers are based on data from the U.S. Census Bureau and local census offices. 


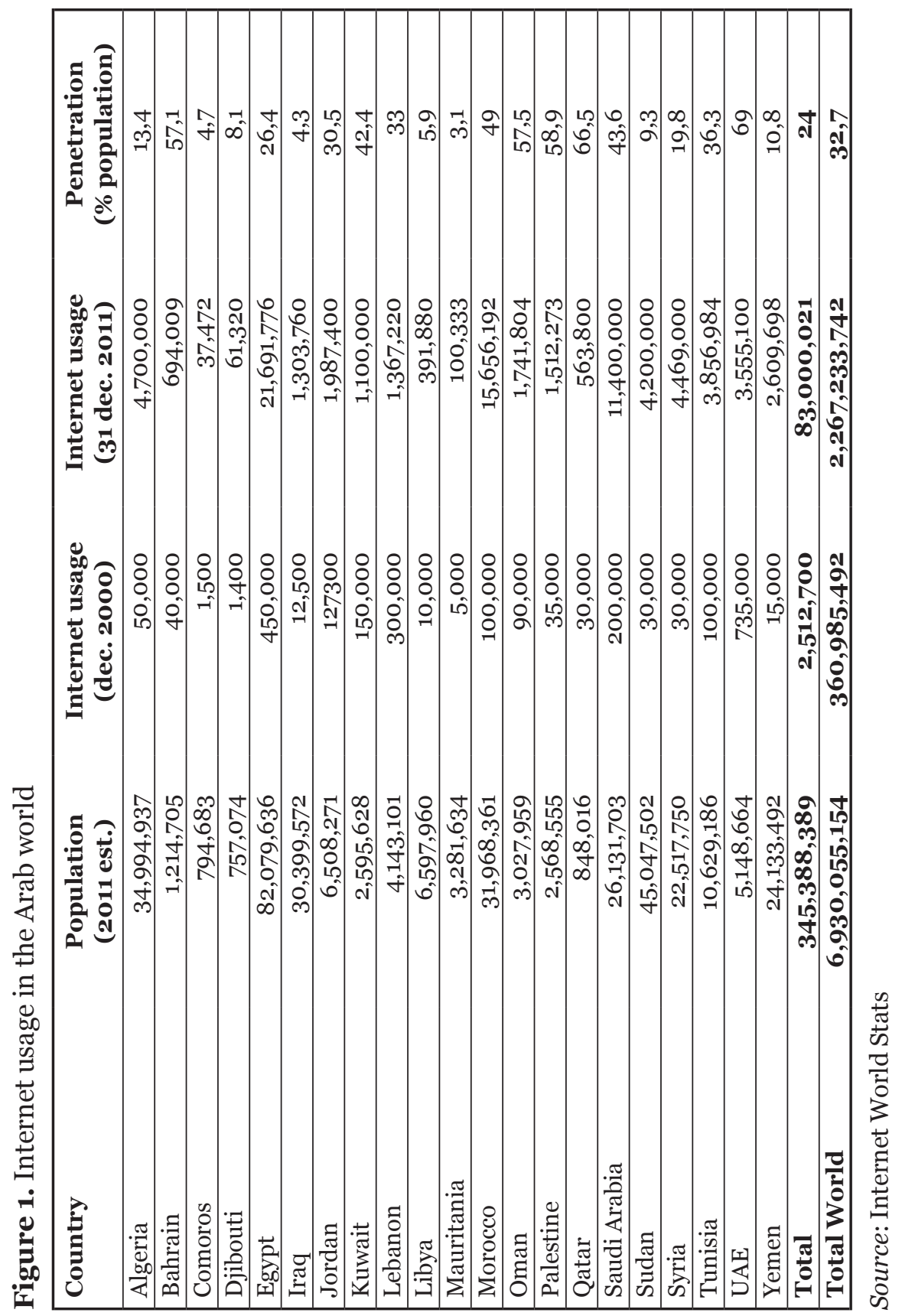


detail how Islamic fundamentalist groups quickly achieved a leading position on web-mobilization by targeting a well-defined audience. Traditional media outlets have also been very active in uploading information online in order to keep up with their commercial needs. As Lynch (2006) argues, "broadcasting and the Internet have revitalized the Arab press".

One of the most popular outcomes of this new online communication revolution in the Arab world has been the blogs: they have become the most effective tool to practice the right to freedom of expression. In 2009, there were approximately 35,000 active Arabic language blogs and several thousand Arabic blogs with mixed use of Arabic, English and French (Etling et al. 2009). Again, as it happened with the satellite television, the Arab youth have been the greatest consumers of this new media. The information revolution and social media products allowed Arab youth to develop their own social and cultural codes; they empowered the youth by freeing them from social constraints (Bishara 2012).

It is worth mentioning that it is not a simple coincidence that a very young population of Arab activists was in fact the real power that drove the uprisings in 2011. According to the Arab Development Challenges Report (2011), half of the total Arab population is under twenty-five, a youth which is specially suffering from high rates of unemployment (23.8\% in 2011) ${ }^{24}$. This leaves this mass of young population in a good position to fight for better economic conditions and for a democracy most of them have never experienced. Not only blogs have opened up the access to express one's opinion on public matters, but they have also given the chance to do so in an Arabic colloquial language, which has made this media outlet more attractive to the majority of the Arab population, especially the youth. People do not need to use the formal classical or Modern Standard Arabic used in the traditional media; the street-spoken language is not only accepted but also expected in the Arab blogosphere.

24. Accessed August 6, 2012: http://204.200.211.31/Update_Feb_2012/ADCR_En_\%20 8-2-2012.pdf 


\subsection{THE ROLE OF SOCIAL MEDIA IN THE ARAB UPRISINGS: AN OPEN DEBATE}

The new media technologies and their role in helping democratization processes have clearly been in the midst of a vivid debate both in the media and in the academic circles since the Arab uprisings begun in early 2011. It has been said, on the one hand, that social media tools, including Facebook, YouTube and Twitter, can increase freedoms the same way the printing press did in democratizing Europe (Alterman 2011; Auer 2011; Beaumont 2011; Cottle, 2011; Filiu 2011; Ghannam 2011; Herrera 2011; Hounshell 2011; Khoury 2011; Lynch 2011; Mansour 2012; Nelson 2008; Shirky 2011; and Zhuo, Wellman and Yu 2011). There are also many others who argue, on the other hand, that any forms of cyber-activism are doomed to be simply very good tools for a quicker organization and communication in revolutionary processes but that they are not sufficient for sociopolitical transformation (Barrons 2012; Dajani 2012; Hassan 2011; Khamis et al. 2012; and Mason 2012). It is perhaps too soon to conclude that either one is correct, yet both visions are necessary to understand to what extend and in which way online social networking played a role in the Arab uprisings. In any event, the analysis should come in two phases. First, attention should be paid at the way new media tools had an immediate effect on the uprisings. Afterwards, there should be a careful examination on the impact social media have had -and will have- on the revolution.

Marc Lynch (2011), who has extensively written on the outcomes of the Arab uprisings, argues that, while it is too soon to know whether these uprisings will have brought about fundamental transformations of any of these regimes, they have already decisively reshaped the nature of regional politics and powerfully challenged many assumptions about the power and durability of the authoritarian Arab state. Lynch considers that the thrilling transformation of information environments in the Arab world - shaped by the rise of satellite television and by the progressively significant Internet-based new media such as blogs, Facebook, Twitter, and Youtube- over the last decade has 
changed the individual ability to organize for collective action, and the transmission of information from the local to the international level. In a way, social media has changed the way societies challenge authoritarian Arab regimes, although the lessons to be learned, as Lynch reminds, are more complex.

During the uprisings, citizen journalists became a major source for mainstream media -i.e. satellite televisions and international media - and also a trusted source of information for the Arab community across the region. They helped raise awareness about the regime's brutal practices that, although widely known by the population, had not had the coverage by traditional media due to censorship and fierce state-control. As Hijjawi (2011) points out, citizen journalism "helped alleviate the vacuum of information". Later, and with the help of the new information and communication technologies, activists and opponents could mobilize and recruit a large number of mass populations, whose awareness and concerns about the state's brutality had grown, in a very short time. Social media provided the general population with the necessary means to actually become activists by promoting civic engagement (Alterman 2011). It was useful for the awakening of the "largely dormant, unengaged, and marginalized civil societies in the Arab world", as characterized by Khamis, Gold and Vaughn (2012). User-generated content worked as a call to become an activist and when activism went out on the streets, the protests grew exponentially, transforming what had once been small opposition forces to massive grassroots protests against the regimes.

New media tools did have a role in reducing the costs of mobilization and organization and accelerating the dissemination of information. Yet to what extent social media had an impact in the revolution, especially after the uprisings' momentum beginning of 2011, is a question that should carefully be addressed in perspective. The content editors of the website nawaat.org, a collective blog umbrella for many Tunisian activists that was especially relevant during the uprisings, believe that the role of social media has been largely magnified and that it should only be credited for its catalyzing and organizational 
role, and as a tool for dissemination ${ }^{25}$. Adai et al. (2012) consider that the key role for new media could be its "bridging function", which allows them to inform international audiences and mainstream media reporting, more than they do to local audiences.

According to Robert Hassan (2011), the events fostered through networkable technologies led to a "power vacuum" because, in fact, there were no roots to back it up. The online social movement had neither visible leadership nor power for real change. For Hassan, this is central in understanding why this type of grass-roots dynamics cannot achieve any significant changes if isolated. Samin (2012) has a similar approach in criticizing the leaderless feature of online movements: while social media served as a spur for the Egyptian revolutionary agitation, it proved invalid as a driver of particular political outcomes Jean-Pierre Filiu would probably have arguments against both Hassan and Samin. In light of his ten lessons learned from the uprisings, he believes that leaderless movements, like those in Egypt and Tunisia, have proved to be effective, and that is why other civilian resistances in other countries such as Libya did not have an easy way: autocrats also learn their lessons well (Filiu 2011).

In Hassan's view, the protests "arose out of virtually nothing except a long-standing but unfocussed and largely unacted-upon anger and resentment against their oppressors". He supports his discourse by asserting that real social changes, such as achieving democracy, need to be embedded in durable grassroots activism, which in his opinion, was nearly non-existing in the digitally-networked society that mobilized the masses through Facebook pages, tweets and by uploading videos on YouTube. Hassan's main argument stresses the fact that democratic culture, as we know it from the liberal point of view, needs time and that the new communication technologies have all but "created a destabilization of the world that traditionally gave rhythm to democracy". Thus, Hassan claims that democracy may come with time but that information technologies can only have "the most peripheral of roles".

25. Accessed August 11, 2012: http://nawaat.org/portail/2011/01/19/quelle-twitter-revolution-en-tunisie/ 
Media professor Nabil Dajani (2012) goes even further and argues that the Arab uprisings were not motivated by a strict desire for democracy. He believes that it is more accurate to refer to the Arab revolts in terms of dignity and a need for collective freedom and justice. In terms of the role new social media technology is playing in shaping the events in the Arab region, Dajani clearly says that they have contributed to amplifying the protests and connecting people, but that what really brought about social and regime changes in the Arab countries is what he calls the "folk and traditional" transmission of messages -that is, Friday sermons, music, storytellers and other face-toface communication. Dajani regrets that too little attention has been paid to these forms of dissemination.

Overall, critics have put into question the ability of the young online activists to actually achieve their demands, often too vague and unfocused -in light, for instance, of what was gained in the 2011 parliamentary elections (Khamis et al. 2012). Some claim that they have limitations when it comes to "facilitating political bargaining in constitution-writing processes", as underlined by Alterman (2011). It is agreed though that the revolutionary processes in Tunisia and Egypt had their foundations in a joint force composed by young activists, human rights defenders, opposition groups and labor movements. Had not been for their perseverance and tireless unrest over the past decade, the democratic wave would have probably not been successful (Filiu 2011).

The use of different forms of social media also needs to be considered in the context they are being employed. Underlying social and political dynamics of countries across the Arab region have also led to different outcomes in terms of political change. Among those where mass mobilizations did happen, only a few were capable of overthrowing the authoritarian regime. Some authors have already compared the political contexts that have led to different outcomes. Khamis, Gold and Vaughn (2012) offer a detailed analysis of the similarities and differences between the Egyptian and the Syrian cases. Although in both countries Internet-savvy actors can be seen in all parties of the conflict in what they call a "cyberwar" between the regimes and their 
opponents, they differ in terms of "ethnic, religious, political and communication fabric". Concerning the communication arena, the authors bring attention to the numerous differences between the two countries, namely allowing foreign press to report about the uprisings in Egypt from the inside versus banning foreign journalists to enter the country to cover the events in Syria. Syria learned the lesson well: contrary to what both Egypt and Tunisia did before and during the uprising, there were no Internet blackout episodes, which would otherwise have induced further tension amidst the cyber-activist community (Gonzalez-Quijano 2011). There have also been comparisons between the Egyptian experience and that of Saudi Arabia. Nadav Samin (2012) also argues that sociopolitical differences between societies largely determine the success of opposition movements. For instance, the Egyptian Facebook campaign was nothing less but the culmination of a long struggle of a collective of online activists seeking democracy, stability and freedom, while in Saudi Arabia, a strong economy along with a culturally conservative society have made most citizens less interested in any political change.

However, and despite the differences across countries, "the general trend is revolutionary", as Filiu recalls. Different processes have led to different outcomes but the dynamics that have paved the way for the peaceful movements across the Arab regions have all shared basic goals: a transparent and accountable government, justice and equality, end of emergency laws and police repression, and end of corruption. The new Arab public sphere, provided by satellite television and the new social media, has helped in merging the multifaceted protests emerged throughout the region. In Egypt and Tunisia, the revolts have achieved a first step in their demands - both governments have been overthrown- but the rest of the claims remain on the pipeline.

\subsection{AN ANALYTICAL FRAMEWORK}

In light of the ongoing discussion over the political effects of social media in the Arab uprisings, I propose a case study to determine the 
extent to which new media tools either helped or limited the events in Tunisia and Egypt. The main goal is to establish significant preliminary findings by addressing the question of what role social media have in political change in the context of two particular examples. The election of these two countries is based on the fact that they have been the focus of a significant debate during the first year after the uprisings and, being the first countries that triggered the political unrest throughout the Arab region, the information and data available on the social media usage in Egypt and Tunisia is more accessible for an accurate analysis.

The next section examines the use of social media in these two countries considering four key factors that are in one degree or another directly related to the events: Internet usage, grassroots and opposition movements, mainstream media, and state control. The analysis draws from the following model form of relationship between social media and the four components selected:

Figure 2. Relationship model

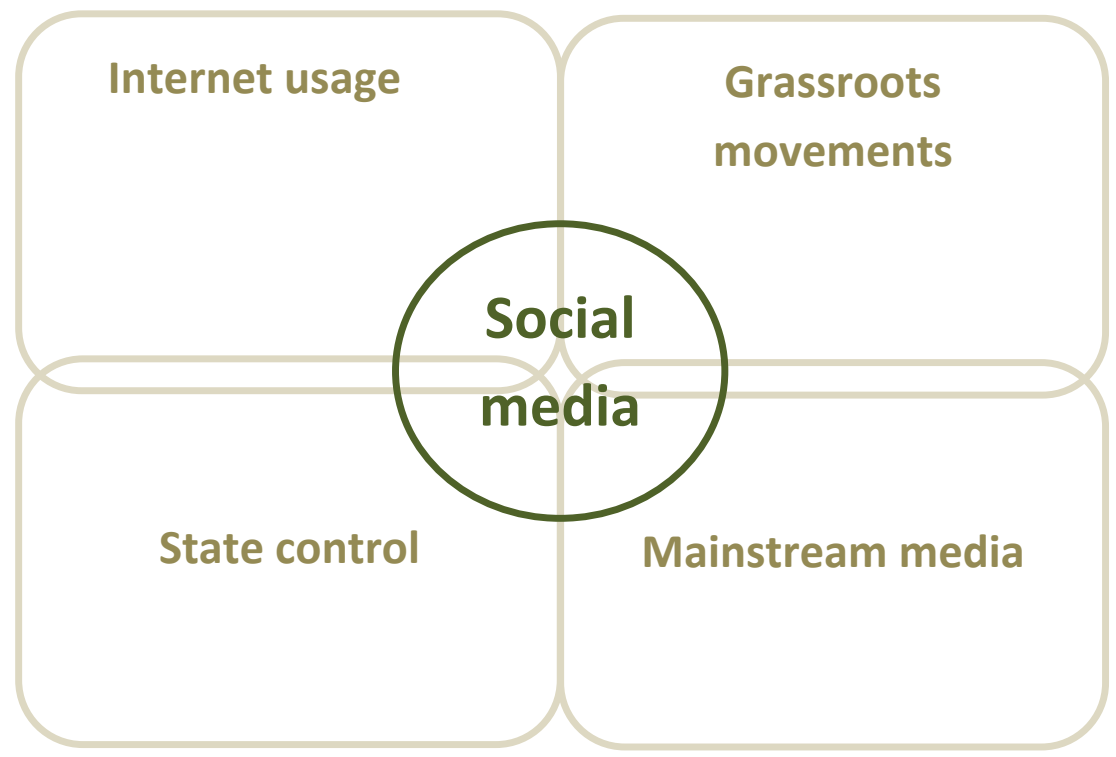


By examining each of these four components and by looking into their relationship with social media, the study shows how online social networks contributed to the revolutions in Tunisia and Egypt. Attention has also been paid to the influence that each component receives from one another in order to better explain the effects in their relationship with social media, although it is not central to the study. On the other hand, there are, of course, elements that are not considered here because they go beyond the scope of this study, although they should be taken into account in a future research of this question. For instance, I did not consider the relationship between cyber-activists in Tunisia and Egypt and those of other Arab countries. Content-wise, this study does not take into account the type of discourses that helped shape the mass mobilizations: a discourse analysis of the social media messages that were generated during the protests would be necessary to determine whether there was any causal effect between the message and the outcome of the uprisings.

The study is based on available information and material obtained in 2011, although it also includes documents and literature analysis including publications and electronic material on past trends and future constraints. It draws mainly from data from the Internet World Stats and data gathered by the Dubai School of Government's Governance and Innovation Program and the Berkman Center for Internet \& Society at Harvard University. Variables used in the study of this data include Internet penetration, social media usage, and language preference in the web-based social networks, among others. For the purpose of this paper, there is also a specific focus on the available data of Internet and social media use during the uprisings.

The study also shows evidence of the use of social media before, during and after the uprisings in Tunisia and Egypt, from relevant web-based social networks to key online activists who, through their testimony, reflect the undeniable relationship between social media and the uprisings. Finally, so as to limit the study in its scope, I have chosen to frame the analysis by focusing only on four Internet-based applications: blogs, YouTube, Facebook and Twitter. 


\section{CASE STUDY: THE 2011 \\ TUNISIAN AND EGYPTIAN \\ REVOLUTIONS}

This analysis explores the ways by which the use and impact of social media in Tunisia and Egypt were connected to the internet penetration in both countries, to the main grassroots movements that had a significant role during the uprisings of 2011, to the traditional media and to the authoritarian regimes. It also brings an account of how social media were used during the revolution in Tunisia and Egypt.

\subsection{INTERNET AND SOCIAL MEDIA USAGE}

Internet penetration in both Egypt and Tunisia has exponentially grown in the past decade. In the case of Egypt, the number of people using the Internet by the end of 2011 was over twenty-one million (26.4\% of the country's total population), almost fifty times that of the year 2000. In Tunisia, the increase was also significant: from 100,000 users in the year 2000, the number raised up to nearly four million users by the end of 2011 (36.3\% of the country's total population), which represents an increase of almost forty times (see Figure 1 for exact numbers). Of course, the increase in the number of Internet users is a worldwide trend (around $600 \%$ in the past decade). However, the rates at which Internet usage have grown in the Arab world, from North Africa to the Middle East, go far beyond the global average.

In terms of social media usage, the growth rates of usage have also been raising relatively fast. According to the Arab Social Media Report (2011), attention should be paid to the fact that the number of Facebook users in the Arab world increased by $30 \%$ in the first quarter of 2011, with Egypt constituting nearly a quarter of total Facebook users in the Arab region. However, the Arab states of the Persian Gulf lead the rates of Facebook user penetration (Figure 3). Interestingly, almost two million new users joined Facebook in Egypt between 5 January 2011 and 5 April 2011. 
According to this report, by April 2011 Egypt had 6.5 million Facebook users, representing a $7.66 \%$ of the country's total population, as opposed to the 4.5 million of users in January 2011. Tunisia had 2.3 million of Facebook users by April 2011, representing a 22.49\% of the country's total population ${ }^{26}$. Demographically, $75 \%$ of Facebook users in both Egypt and Tunisia were found to be twenty-nine years old or younger.

Figure 3. Facebook user penetration in the Arab region (April 2011)

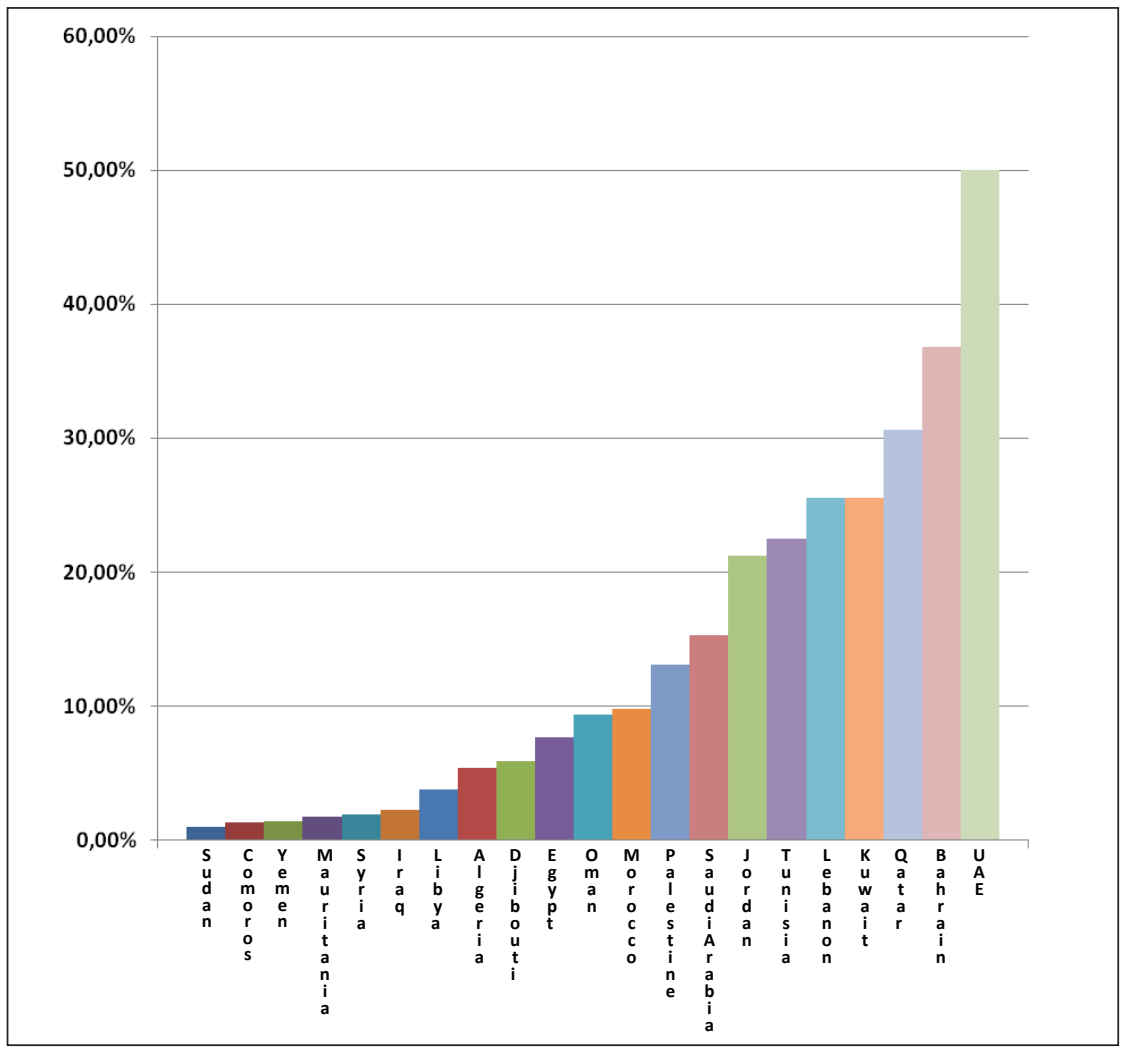

Source: Arab Social Media Report, 2011

26. These figures rose even more during the months following the uprisings. According to the Arab Social Media Report (2012), this increase -impressive in the case of Egyptcould be influenced by "the sense of empowerment and their ability to create change and cultural attitudes at the society and community level”. 
On the other hand, the number of Twitter users was far below the Facebook universe. While Egypt was also among the top five Arab countries in terms of active Twitter users (131,204 in average between 1 January and 30 March 2011), Tunisia was far below this number (35,746 active users). Nevertheless, Twitter was not as broadly used as Facebook neither in Egypt nor in Tunisia. The Twitter penetration rate in Egypt during the first months of 2011 was $0.15 \%$ and in Tunisia it was $0.34 \%^{27}$. The most popular trending hashtags across the Arab region in the first quarter of 2011 were \# egypt, \#jan25, \#libya, \#bahrain, and \#protest ${ }^{28}$. The top trending terms in Egypt and Tunisia were \#jan $25^{29}$ and \#sidibouzid ${ }^{30}$, respectively. The \# egypt hashtag increased from 122,000 tweets on the eve of the revolution to 1.3 million tweets right after the 25 January demonstration. However, approximately two thirds of all tweets were in English and almost 70\% were retweets (Barrons 2012).

With regard to the language, Facebook experienced a massive increase in Arabic-speaking users after introducing its Arabic interface in February $2009^{31}$. In fact, Twitter did not have an Arabic language interface until March 2012 ${ }^{32}$, and this seems to have inhibited the growth of its Arabic-speaking user base. As the Arab Social Media Report (2012) points out, Arabic is currently the fastest growing language on Facebook. Looking at the Facebook language preferences during the uprisings, Egypt opted for an equal use of both Arabic

27. It is interesting to see how the trends turned to the complete opposite one year after the uprisings. According to the Arab Social Media Report of July 2012, the Twitter penetration rate in Egypt had raised to $0.35 \%$, while in Tunisia it had dropped to $0.11 \%$.

28. In May 2012, two months after Twitter launched its Arabic interface, the top Twitter trends in the Arab region were \#bahrain, بحـــين (Arabic for Syria), ســــ (Arabic for Bahrain), \# egypt, \#syria, and \#kuwait

29. The volume peak of \#jan25 was on February 11, 2011, when President Mubarak stepped down.

30. \#sidibouzid had two volume peaks: the first, on January 14, 2011, during the protests; the second, on February 27, 2011, when a new prime minister was appointed.

31. See http://arabcrunch.com/2009/02/facebook-launches-arabic-beta-watch-out-arabic-social-networks.html

32. See http://www.thenational.ae/news/uae-news/coming-to-the-web-twitter-in-arabic and http://www.globalpost.com/dispatch/news/business-tech/technology-news/120307/ twitter-launches-arabic-farsi-hebrew-urdu 
(49.88\%) and English (48.98\%), while Tunisia clearly preferred to use French (94.60\% over 1.56\% Arabic and 2.72\% English) 33 .

The video-sharing platform YouTube is one of the social media tools that have had a greater impact across the Arab countries. YouTube views in the region grew by $120 \%$ in the first half of $2012^{34}$. In Egypt, video uploads grew $150 \%$ and in Tunisia, the number of uploads increased by $420 \% 35$.

As far as the use of blogs is concerned, a study by Etling et al. (2009) reveals that the Arabic blogosphere is organized around countries. According to this study, Egypt is the largest cluster of active blogs, which are classified by their focus and goals in many different areas of interest. One of the main findings of their analysis is that bloggers in Egypt seem to have traditionally been connected to political movements, showing support for the various active campaigns and using strong signals of political discourse. The study breaks down the Egyptian network of blogs into five areas of interest: secular reformists (close to the Kefaya movement); wider opposition (with preference for the Tomorrow party); Egyptian youth (mainly young female oriented blogs focused on women's issues and some politics); Egyptian Islamic (engaged on the discussion of Islam); and Muslim Brotherhood (with a very active online presence). In the case of Tunisia, bloggers are grouped in a cross-country cluster that includes the whole Maghreb area and who are mainly critical of both internal and external politics at large. While Egypt has the highest proportion of female bloggers in the Arabic blogosphere, the Maghreb cluster is extremely represented by men.

33. Over the months after the uprisings, Arabic language has grown as the most preferred language for Facebook users in Egypt (59\% over 41\% English). In Tunisia, however, only a very small percentage of Facebook users are utilizing the Arabic language interface, as opposed to a big majority who still prefer to use French. Twitter users have also shown their interest in using the Arabic language after it became an interface of this microblogging application in March 2012, although in Egypt the percentage of tweets in Arabic and English is even.

34. Arab Social Media Report (2012)

35. Country data in 2011 compared to 2010. 


\subsection{SOCIAL MEDIA AND GRASSROOTS MOVEMENTS \\ BEFORE THE REVOLUTIONS}

The protests and resulting ousting of longtime leaders in Tunisia and Egypt evolved in a relatively brief time frame. It took less than four weeks -from 18 December 2011 to 14 January 2012- of street demonstrations to force President Ben Ali to flee from Tunisia. In Egypt, President Mubarak resigned from office eighteen days after the protests had begun on 25 January 2011. Yet despite of the speed at which the events unfolded, the critical masses had long been active in both countries and what had started as a small, albeit influential, group of urban, middle-class young Tunisian and Egyptian activists, could rapidly expand through a snowballing effect.

During Ben Ali's regime, opposition movements, human rights activists and journalists constantly lived under a severe state of repression. Using Internet to communicate posed a serious risk of being arrested and tortured. Nonetheless, blogging emerged as one of the most useful forms of disseminating information and countering the official discourse. Tunisian bloggers became very influential in mobilizing the masses. In 2001, Zouhair Yahyaoui created TUNeZINE, a satirical political online magazine that included numerous articles criticizing Ben Ali's government, censorship and human rights' abuses. Yahyaoui was arrested and imprisoned in 2002. Two years later, in 2004, human rights activists Sami Ben Gharbia, Sufian Guerfali and Riadh Guerfali created an independent collective blog portal, Nawaat.org, which became a platform for Tunisian opposition forces. Since its launch, and because of its persistence in informing on human rights abuses and lack of press freedom, it was regularly blocked by the Tunisian authorities.

Tunisian Internet blogger and activist Lina Ben Mhenni gives a great and detailed account of the way cyber-activists would challenge Ben Ali's regime in her book (2011), “Tunisian Girl, blogueuse pour un printemps arabe". According to her, the community of Tunisian bloggers was determined to act against torture and censorship by all means possible. Ben Mhenni was one of the few bloggers who used her real 
name when writing against censorship and repression. Her website and other media tools like her Facebook and Twitter accounts were censored by Ben Ali's regime, although she could use a proxy to access her blog ${ }^{36}$. Ben Mhenni's role, along with that of other Tunisian prominent cyber-activists, was crucial in organizing an anti-censorship demonstration in May 2010 in the city center of Tunis, a critical point of what she considers to be the real start of the Tunisian revolution. Social media tools were extensively used to organize the protest and coordinate efforts aiming at the success of the march ${ }^{37}$.

In Egypt, political activists have also been very active in the blogosphere; they had also been using new media tools to mobilize citizens for some time before the 2011 uprising. The Kefaya group, for instance, made use of the raising Egyptian blogosphere since 2004. Their efforts were aimed at seeking political change, demanding that President Mubarak step down and hold direct, competitive elections (Radsch 2008). A few years later, the April 6 Youth Movement, also employed new technologies such as cell phones, blogs, Facebook, and YouTube for the labor protests in 2008. The Facebook group's aim was to support the textile workers in El-Mahalla El-Kubra in their protest against rising food costs and in demand of better wages. Members of this group organized strikes, protests and demonstrations throughout the country using social media tools, which allowed them, for example, to attract up to 70,000 members on their Facebook site (Filiu 2011 $)^{38}$. Regardless of the success of their strike call, dissidents were clashed by the Egyptian security forces ${ }^{39}$.

In June 2010, Khaled Mohamed Said was beaten to death by the state's police in Alexandria ${ }^{40}$. Photos of the disfigured corpse of the

36. Accessed August 30, 2012: http://www.voanews.com/content/tunisian-blogger-undeterred-by-censorship-112948869/157156.html

37. Accessed August 30, 2012: http://advocacy.globalvoicesonline.org/2010/05/27/anticensorship-movement-in-tunisia-creativity-courage-and-hope/

38. Accessed August 30, 2012: http://www.pbs.org/wgbh/pages/frontline/revolution-incairo/inside-april6-movement/

39. Accessed August 30, 2012: http://news.bbc.co.uk/2/hi/middle_east/7332929.stm

40. Accessed August 30, 2012: http://www.egyptindependent.com/news/alexandria-policemen-beat-young-man-death-says-rights-group 
young man taken by his own brother on his mobile phone rapidly spread through the online social networks, exposing the tragic event to millions of Egyptians and making Said's death a national scandal ${ }^{41}$. Soon after a Facebook page, "We are all Khaled Said" - was set up with the initial goal of bringing the killers to court to pay for their crime. However, it quickly transformed into something much bigger, leading a movement that would campaign against torture and rights abuses in Egypt. This group eventually called for a Day of Anger against "Torture, Corruption, Poverty and Unemployment” for January 25, 2011 ${ }^{42}$. Activists of the April 6 Youth Movement were involved in this group, but it was Google executive Wael Ghonim who fueled the massive mobilization (Ghonim 2012).

The story of Wael Ghonim, an Egyptian Internet activist "who loves challenging status quo", as he describes himself on his Twitter account, has been extensively covered on the media ${ }^{43}$. In his recently released book, Revolution 2.0, he provides a thoughtful account of how the "We are all Khaled Said" Facebook page was created and how it evolved into a rallying point for thousands of educated Egyptian youth. As he expresses in his narration of the story, he sees Internet as "the key vehicle to bringing forth the first spark of change". According to Ghonim, the Facebook page helped activists to persuade and mobilize "regular non-politicized young men and women" that would otherwise not feel engaged enough with the cause. Ghonim, who had decided to act as an anonymous administrator of the page, planned the January 25, 2011 march after asking the members of the page, in a very inclusive way, what would happen if Egyptians took the streets the same way Tunisians had done just a few weeks before. He started rallying for January 25 with the following message:

41. Accessed August 30, 2012: http://observers.france24.com/content/20100616-deathkhaled-said-one-police-blunder-many-egypt-protests-police-brutality

42. See article of Linda Herrera, "Egypt's Revolution 2.0: the Facebook Factor", published in Jadalyya.com, on 11 February 2011. Accessed June 30, 2012: http://www.jadaliyya. com/pages/index/612/egypts-revolution-2.o_the-facebook-factor

43. Accessed August 30, 2012: http://www.bbc.co.uk/news/world-middle-east-12400529; http://www.npr.org/2012/02/o9/146636605/wael-ghonim-creating-a-revolution2-o-in-egypt; and http://www.cbsnews.com/2100-18560_162-20031701.html 
"To the ultras of Ahly, Zamalek, Ismaili, and Itihad soccer teams... If you exert the same effort you do for any soccer match on the $25^{\text {th }}$ of January, you will help Egypt change... Let us all be ultras of Egypt... Let us all take action and take to the streets... Who among us is an ultras member and prepared to cheer for Egypt?” (Ghonim 2012).

Nevertheless, Ghonim was aware that, in order to have a greater impact and be successful, there was a need for reaching a large number of people, asking members for help in spreading the message by sharing the event's details, sending text messages, printing fliers and inviting people in person to the march. And it worked: the event had gained over 100,000 confirmed attendees in just ten days; news about the January 25 protests spread to both streets and the media; and, finally, thousands of Egyptians participated in the march.

These examples show how Egyptian activists had used Facebook to campaign, create a massive support-base and mobilize the masses before the 2011 protests. But the message that brought millions of Egyptians to the streets had also been broadly spread by other opposition movements, from Islamists to nationalists, to liberals and reformers ${ }^{44}$. The Muslim Brotherhood, for instance, opted as early as 2004 to launch its own website in both Arabic and English and blog their opinions against Mubarak's legitimacy, making use of alternative media to spread their message and even setting a counter agenda (Richter 2008). They even created their own Facebook-like application ${ }^{45}$.

As described above, grassroots movements in both Tunisia and Egypt, small in number but potentially significant, were able to built up a momentum of ripeness for change and, at that point, different social media tools had different roles. Khamis, Gold and Vaughn (2012) explain them as follows:

44. Accessed June 30, 2012: http://www.guardian.co.uk/commentisfree/2011/feb/o2/ who-is-behind-egyptian-protests

45. Accessed August 30, 2012: http://www.thenational.ae/news/world/africa/muslimbrotherhood-launches-its-own-version-of-facebook 
"Facebook was effective as a means of finding others with similar political views and planning street protests; YouTube was well suited to promoting citizen journalism by broadcasting activists' videos which were then picked up by satellite television channels and seen around the world; and Short Message Service (SMS) and Twitter enabled on-themove coordination and communication. Twitter was also used for outreach to the international media and diasporic communities.”

It is important to underline that what happened in Tunisia first and Egypt later was a meeting point of both online and offline political activism. Egyptian activists had been trying to forge a revolution using various social media tools for a decade, with little sustained success (Adai 2012). In 2011, the minority represented by cyber activists met the majority of on-the-ground activists during the uprisings. They shared ideals, objectives and motivation and they saw that by joining their strategies and strengths they would probably have better options to achieve their goals. Many online young activists entered into a position of power for the first time using social media, feeling "enlightened as never before" (Auer 2011).

\subsection{A TOOL DURING THE UPRISINGS}

When Mohamed Bouazizi set himself on fire in the city of Sidi Bouzid on 17 December 2010, riots were quickly organized the day after. Tunisian youth had long been infuriated and this event only fired them up. The protests went largely unnoticed, although many participants with cell phones and video cameras recorded the protests and posted them online on their Facebook and Twitter accounts. However, social online platforms like Nawaat.org soon collected those stories and started to publish them through their sites, from where international media would finally get footage to fill in their news streaming.

Bloggers helped spread news of the protests around the country using their personal websites, their Facebook pages and their personal Twitter accounts. They would create their own content, post it online 
or send their messages directly through Twitter to the media. They would also film events with their cell phones and upload their videos of the protests to YouTube. Although only a few could have access to them, those videos were rapidly captured by the international community and media. Collective sites like Nawaat.org were particularly relevant and active in feeding the population with information that would have otherwise been totally hidden by the state's communication flows ${ }^{46}$. Lina Ben Mhenni, for example, was one of the many other Tunisian activists who, not only wrote and posted photos online of what she was directly seeing on the streets, but also accompanied international media reporters to the areas were the events were occurring (Ben Mhenni 2011). Although the Tunisian government tried by all means to interfere with these dynamics, they could not adapt as quickly as they would have needed to the situation.

When Egyptians saw what Tunisians had achieved after four weeks of peaceful protests, they felt empowered to do the same in Egypt. Wael Ghonnim's statement is clear: "By January 14, I started to believe that we could be the second Arab nation to rid itself of its dictator" (Ghonnim 2012). The Facebook page "We are all Khaled Said", which had been attracting members by the hundreds daily during the months previous to the revolution and which was already preparing the 25 January march, posted a message of solidarity with Tunisia and with signs of hope that Egypt would follow:

"[...] O youth of Egypt, listen so you know that no government is stronger than its people... A strong salutation of respect to the free people of Tunisia!"

Tunisian and Egyptian activists had been collaborating over the two years before the revolution. They kept a line of communication, sharing best practices and ideas, brainstorming on the use of technology to evade surveillance, and trading practical tips on how to stand up to rubber bul-

46. Accessed September 2, 2012: http://thelede.blogs.nytimes.com/2011/o1/14/arab-bloggers-cheer-on-tunisias-revolution/ 
lets and organize barricades ${ }^{47}$. By the time the demonstrations of 25 January 2011 happened, the Egyptian youth felt they were empowered, prepared and confident that they would succeed. A few days before the demonstrations Asma Mahfouz, a young Egyptian activist posted a video ${ }^{48}$ on Facebook that soon became very influential as soon as it was uploaded to YouTube ${ }^{49}$. YouTube was one of the most used online tools among Egyptians who were seeking alternative ways to be informed about the events. One of the most watched videos during the protests was a montage about Egyptian's frustrations under Mubarak's regime. It was posted on YouTube by Tame Shaaban, a young US-born Egyptian film maker. His film, albeit blocked in Egypt, managed to get millions of views ${ }^{50}$.

By this point, Twitter had already come into the scene as a tool for protesters to communicate among themselves first and inform about the events later. Idle and Nunnis (2011) book "Tweets from Tahrir" collects hundreds of the posts that were generated during the protests. In some, it is clear how Egyptian activists chose this social platform as a way of communication during the uprising.

ManarMohsen: "Those tweeting about the protest in Egypt, please use the hashtag \#Jan25 in order to spread any information"

Many considered themselves as citizen journalists and used the application to get the word out with information, photos and videos. Some of the tweets collected from the first day of the Egyptian revolts show this self-attributed reporters' role:

tarekshalaby: Today's our day as \#CitizenJournalists to cover and share the truth freely. Regardless of the outcome we are winners cuz we're a team \#jan25

47. Accessed September 2, 2012: http://www.nytimes.com/2011/o2/14/world/middleeast/ 14egypt-tunisia-protests.html?pagewanted=all

48. Accessed September 2, 2012: http://www.youtube.com/watch?v=SgjIgMdsEuk

49. Accessed September 2, 2012: http://www.nytimes.com/2011/o2/o2/world/middleeast/ o2iht-lettero2.html

50. Accessed September 2, 2012: http://www.huffingtonpost.com/2011/o1/29/egypt-protest-video-montage_n_815822.html 
Information on how the demonstration was being unfolded and warnings on security forces attacks were also communicated via Twitter:

TravelerW: \#jan25 violence on the gala bridge. W pushed through -but now we're stck on the bridge

Ghonim: We got brutally beaten up by police people \#Jan25

Norashalaby: Someone is hurt. Need a doctor

Ashrafkhalil: \#Jan25 police and protestors in tahrir all gagging on teargas

During the day, the government blocked Facebook and Twitter for a few hours, but activists would find their way via proxys. Moreover, the blockage would only encourage even more the activists:

3arabawy: to break the block on Twitter use this proxy: $\underline{\text { http://hi- }}$ demyass.com/ \#Jan25

Ghonim: The Egyptian government started to take really stupid actions that will result in nothing but encouraging more people to protest \#Jan25

Sandmonkey: This is becoming the region first telecommunication civil war. Our internet \& smart phones are weapons they won't allow us to have. \#jan25

When the Egyptian state authorities decided to cut the Internet access for six days on January 28, some attempts were made to get around the blackout, but for the most part they were mostly attempted by foreign journalists with satellite phones (Barrons 2012). But thousands of Egyptians were already demonstrating on the streets and they continued to do so during the days to follow. Despite the blockage, some activists managed to report the events via landlines or borrowing the satellite links of the international media (Idle and Nunnis 2011):

Gsquare86: I have internet access from an 'unkown' location, the people are in MILLIONS in the streets and will NOT stop until MUBARAK is OUT! 
Sharifkouddous: People asking how I'm tweeting from Egypt, we are using a work-around. Internet is still down and I can't send pics Sandmonkey: no internet in Egypt. Calling in tweets to a friend in \#Jordan \#Jan25 \#Egypt

monasosh: @marcducharme I run from tahrir to where we have internet, tweet and upload pics and videos then run back:)

monasosh: This is getting better, the awesome @3arabawy has joined us here at the "Tweeting center of the revolution" \#Jan25

ashrafkhalil: \# Jan 25: Tweeting via my lovely wife abroad: last surviving ISP finally shut down last night

Wael Ghonim was arrested on 27 January 2011 and he was blindfolded and detained during eleven days. While many other activists had been detained during the protests, the thirty-year-old marketing executive for Google's case was especially significant. First thing he did after his release was to appear on a Dream TV show to tell his story ${ }^{51}$. As it was revealed that Ghonim had been the driving force behind the "We are all Khaled Said" Facebook page, the news was decisive for many Egyptians, who suddenly felt deeply stimulated by his story ${ }^{2}$. Tweets after Ghonim's interview grew in an ever motivating tone:

NevineZaki: everyone is crying, EVERYONE @Ghonim

Sandmonkey: A revolution organized by facebook, spread by twitter and organized by a guy working for Google. \#jan25 \#ILOVEOURREVOLUTION

MennaAmr: I've been terrified this revolution would fade but @Ghonim made that impossible. Thank you for being one hell of an inspiration for everyone.

51. This interview can be seen at Dream TV's website. Accessed September 2, 2012: http:// alive.in/egypt/blog/2011/02/07/dream-tv-interview-with-wael-ghonim-part-1-withenglish-subtitles/

52. Accessed September 2, 2012: http://blogs.wsj.com/dispatch/2011/o2/o8/the-interview-with-wael-ghonim-that-galvanized-protesters/ 
On 11 February 2011, Vice President Omar Suleiman announced that Mubarak had resigned the office of president. Activists on Tahrir Square who had been tweeting what had been happening live during days were aware of what that meant for press freedom:

3arabawy: In dictatorship, independent journalism by default becomes a form of activism, the spread of information is essentially an act of agitation.

3arabawy: People we will get free press. We fought for it, and we got it. No RED LINES ANYMORE! \#Jan25 \#Press \#Journalists

\subsection{THE ROLE OF MAINSTREAM MEDIA: COMPLEMENTARITY OR DEPENDENCE?}

It has been argued that the importance of social media in the Arab revolts of 2011 resides in its relation with traditional media. As seen above, Facebook, Twitter and YouTube were the main tools used by activists to communicate with each other promptly and to pass the message internationally. Yet the role of television - especially satellite television was crucial to the events in the making. In Tunisia and Egypt, Arab satellite televisions made an around-the-clock media coverage of the uprisings; Al-Jazeera was central to bring the message throughout the countries - and the region - and it restlessly worked to broadcast live images of the unrest, interviews to key leaders and analysis of the events as they were unfolding (Filiu 2011). But their role would not have been as strategic as it was, had citizen journalists not been reporting on the events so instantly. Satellite televisions would take the raw material from online sources and immediately broadcast them to the big audience. Citizen journalism improved both quantity and quality of media coverage in mainstream Arab media (Khamis et al. 2012). As Alterman (2011) describes, "television drove them (the events), framed them, legitimized them, and broadcasted them to a wide audience".

During the revolts in Tunisia, the state's strict control over print and broadcast media blindfolded what was happening on the streets. 
State-owned television and radio stations paid little attention to the events and, when they did, they would refer to them as isolated situations. What put Tunisia on the spot, especially internationally, was AlJazeera, through its debates and news streaming. Being banned inside Tunisia for years, Al-Jazeera got awareness about the events in Tunisia thanks to thousands of citizen journalists who, with their user-generated content, helped alleviate their vacuum of information (Hijjawi 2011). In order to fill people's screens, Al-Jazeera, as well as other international media such as France24, was relying on cellphone videos sent by bystanders and call-in interviews. In doing so, it was able to bring the images to a Tunisian and regional audience. Once the revolts started, Al-Jazeera quickly stood beside the Tunisian protestors and their demands. It covered the protests in Tunisia and protesters' actions got 24-hour exposure (Alterman 2011). After the fleeing of Ben Ali on 14 January 2011, many Tunisian television stations overtook AlJazeera in its role of informing on domestic issues, although most of the television professionals were still highly attached to the old regime (Kilani 2011).

In Egypt, social media became the primary source of mainstream media and, at the same time, news coverage of mainstream media was the origin of most of the information circulated through social media. A study by Nanabhay and Farmanfarmaian (2011) shows evidence on how new and old media had a complementary role in amplifying the events. In this study, the process of communication and information of Egypt's revolution is based on a first phase, in which social media played a central role in setting the agenda, and on a second phase, when mainstream media amplified the message that was being communicated by social movements via social media. This two-phased analysis explains how the initial coverage of the events was led by citizens - traditional media was slow in informing and producing videos on 25 January 2011, the first day of protests. Al Jazeera, for example, focused most of its attention to the Palestine Papers investigation, to which it had devoted its main newscast for the past two days, leaving only a small percentage of its broadcast to the protests in Egypt (Hijjawi 2011). According to Nanabhay and Farmanfarmaian's study, the 
audiences' clear preference for the Egypt protests made them seek information on 25 January mainly from online sources. But once mainstream media shifted its attention to what was happening in Tahrir Square, audiences rapidly turned to television.

The role of Al-Jazeera in informing about the uprisings was especially relevant as of the first day of the Internet blackout (Barrons 2012). In fact, the $24 / 7$ television coverage of the events started precisely on 28 January and it was on that date that Al Jazeera for the first time referred to Egypt's demonstrations as a revolution (Alterman 2011). The importance of the mainstream media coverage was quickly grasped by the protesters. They even erected a huge screen to broadcast Al-Jazeera live in Tahrir Square and, after Mubarak's resignation some raised a banner thanking the Egyptian armed forces and Al-Jazeera (Samin 2012).

4.5. STATE CONTROL THROUGH SOCIAL MEDIA:

FROM BLACKOUTS TO CYBER WAR

Ben Ali's government in Tunisia was long known for being one of the most sophisticated cyber-censorship regimes in the world. As Alterman (2011) points out, the Tunisian authorities won its reputation "for being extremely internet-savvy and using its own tech-mechanisms for blocking sites and monitoring each and every single movement cyber-activists would want to do against the regime". Tunisia used a product primarily marketed to business, Secure Computing's SmartFilter program, to exert its censorship strategy by altering the block page functionality of that program to deliver a false error message to users (Deibert 2009). The "Error 404 Not found" message that comes up on computer screens was widely known by cyber-activists in Tunisia. They even created a virtual character called "Ammar 404", which was featured with the government's censoring scissors (Ben Mhenni 2011). According to a study conducted in 2005 by the OpenNet Initiative 53 , an informal, less subtle method of content regulation was also

53. See http://opennet.net/ 
common in Tunisia when authorities irrupted into Internet cafes and arrested those who are accessing prohibited sites.

Activists had to face several blackouts - Facebook and Twitter were sometimes cut off and hundreds of personal blogs and critical pages were shut down - but despite being closely monitored and trailed by the secret police, they managed to use proxy websites, mainly based in Europe, to overcome the regime's restrictions (Filiu 2011). Moreover, they soon developed an acute system of counteracting the authoritarian censorship thanks to a varying set of creative approaches, which allowed them to continue to spread ideas, information and accounts of brutality of Ben Ali's regime.

By the end of 2010, the circulation among the Tunisian youth of the WikiLeaks documents that revealed Ben Ali's corruption put the regime on alert. The government tried to cut off the leaks by blocking the site that was exposing the Presiden's family corruption ${ }^{54}$. Government security services accelerated their assault on the Internet, stealing passwords, hacking accounts, spying on activists, and blocking access to some of the more vocal figures, journalists (Bishara 2012). During the four weeks of protest, Tunisian authorities blocked Twitter, although Ben Ali did not shut down the Internet (Ghannam 2011). Tunisian cyber-activists received international support through the Anonymous group, an international network of hackers who took actions against the government's attempts to control the cyberspace in what they called "Operation Tunisia"55. Soon after, several cyber-activists were detained (Ben Mhanni 2011).

Egypt had a different background on internet control. According to the OpenNet Initiative, there is no evidence of Internet filtering in Egypt, although online activists and local bloggers have been harassed and detained for their activities. Although there is no law explicitly empowering the government to block websites, a 2006 court decision

54. Accessed September 2, 2012: http://www.guardian.co.uk/world/2010/dec/o7/wikileaks-tunisia-first-lady

55. The Anonymous group first posted a video on YouTube on 5 January 2011 in which they declared their intentions. The video is available at: http://www.youtube.com/ watch?v=BFLaBRk9wYo. 
said that the government was allowed to "block, suspend or shut down any website liable to pose a threat to national security"56.

As explained above, during the revolution the Egyptian regime attempted to counter the media by many different tactics, from intimidation and arrest of journalists to disrupting all digital networks (Nanabhay and Farmanfarmaian 2011). The most notable of these efforts to control information flows was the Internet blackout. On the night of 27 January 2011, Internet Services Providers (ISP) were shut down by the Egyptian government. Although authorities kept one of the main providers open - the Noor group, whose clients include the Egyptian stock exchange and the National Bank of Egypt - they finally completely cut it off on 1 February $2011^{57}$. The whole country was completely disconnected until 2 February 2011. According to the Organization for Economic and Cooperation Development (OECD), the estimated direct costs of those six days of blackout are over 90 million US dollars, which refer to the lost revenues due to blocked telecommunications and Internet services ${ }^{5}$. When the Internet came back, not only activists were more eager to continue and increase their protests against President Mubarak, but Mubarak's supporters also mobilized through the cyberspace, as they also did on the streets. They created Facebook pages and other online spaces where they severely condemned the anti-regime protests ${ }^{59}$, although they were silenced by online activists.

56. Accessed September 2, 2012: http://en.rsf.org/egypt-court-upholds-government-s-claim27-06-2006,18136.html

57. Accessed September 2, 2012: http://www.aljazeera.com/NEWS/MIDDLEEAST/2011/o2/ 2011210459908692.html and http://www.huffingtonpost.com/2011/o1/31/noor-groupegypt-internet-down_n_816584.html

58. Accessed September 2, 2012: http://www.oecd.org/sti/interneteconomy/theeconomicimpactofshuttingdowninternetandmobilephoneservicesinegypt.htm

59. Accessed September 2, 2012: http://www.rawstory.com/rs/2011/o2/o9/egypt-activists-upper-hand-cyber-war/ 


\section{CONCLUSIONS}

This paper has looked at the use of social media in the 2011 uprisings in Tunisia and Egypt, focusing on their complex relationship with grassroots movements and the authoritarian regimes of both countries and bringing to attention the connection between traditional and new media. The study has shown that social media tools had been used in both countries long before the uprisings started. Activists as well as states used new web-based technologies to their own end: the former as a means of breaking the boundaries of the Arab public sphere and seeking freedom of expression; the latter, aiming at controlling the online discourse and going after those who break the boundaries. It has also presented evidence of the relevance of the role of social media vis-à-vis the mainstream media; while Facebook, Twitter or YouTube acted as tools for engaging, coordinating and communicating a relatively small group of activists, Al-Jazeera and other international media amplified the message, attracted the majority of the population to join the revolts and put pressure on the authoritarian states by engaging international audiences.

The analysis of the role that social media have had on the Egyptian and the Tunisian revolts gives evidence of the impact new media technologies can have on social transformation. They are used as a tool for fastening communication and coordination at a lower cost, although they cannot be seen as catalysts of any revolution by themselves. They are part of a broader media environment and they cannot be dissociated from the overall strategy of power control and agenda-setting of mainstream media. However, social media do have an increasing role in the processes of social transformation, as seen in the contexts analyzed in this paper. It is perhaps too early to determine the long term stability of the political change in countries like Tunisia and Egypt and evaluating the real impact of social media on these changes over the long run will need further research. Nevertheless, social media should be seriously taken into account when studying popular revolts and collective action, as they are tools with a clear influence in these movements. 
Future research on this topic should include an evaluation of the impact of social media on social transformation by examining and comparing the structural factors of different forms of social struggle in one specific region from a historical perspective. This would allow identifying social media's impact on social movements. It would also be useful to study how the different actors of social movements make use of the new media tools to forge the snowball effect of revolutions. The complex dynamics between social media, grassroots movements, mainstream media and authoritarian regimes make it necessary to look at and analyze very carefully all the parties involved in a revolution and their use of social media: who is more influential using social media and what kind of information spread by social media becomes more relevant in a revolution.

\section{REFERENCES}

Abdo, Geneive. 2011. "Green Movement 2.0? How U.S. support could lead the opposition to victory". In The New Arab Revolt: what happened, what it means and what comes next, edited by the Council on Foreign Relations, 163-167. Originally published in Foreign Affairs 90 (1).

- Adai, Sean, Henry Farrell, Marc Lynch, John Sides and Deen Freelon. 2012. "Blogs and Bullets II: New media and conflict after the Arab Spring." Peaceworks No. 80, report published by the United Sates Institute for Peace.

- Alterman, Jon B. 2011. "The Revolution Will Not Be Tweeted.” The Washington Quarterly 34 (4): 103-116.

Anderson, Benedict. 2006. Imagined Communities: Reflections on the Origin and Spread of Nationalism. London: Verso.

- Auer, Matthew R. 2011. "The Policy Sciences of Social Media.” The Policy Studies Journal 39 (4): 709-736. 
- Ayish, Muhammad. 2011. "Television broadcasting in the Arab world. Political democratization and cultural revivalism", in Arab Media, edited by Noha Mellor, Khalil Rinnawi, Nabil Dajani, and Muhammad I. Ayish, 85-102. Cambridge: Polity Press.

- Barrons, Genevieve. 2012. “'Suleiman: Mubarak decided to step down \# egypt \#jan25 OH MY GOD': examining the use of social media in the 2011 Egyptian revolution." Contemporary Arab Affairs, 5 (1): 54-67.

- Beaumont, Peter. 2011. "The truth about Twitter, Facebook and the uprisings in the Arab world." The Guardian, February 25.

- Benkler, Yochai. 2006. The Wealth of Networks. New Haven: Yale University Press.

- Ben Mhenni, Lina. 2011. La revolución de la dignidad. Barcelona: Ediciones Destino.

- Bishara, Marwan. 2012. The Invisible Arab: The Promise and Peril of the Arab Revolutions. New York: Nation Books.

Castells, Manuel. 2008. "The new public sphere: global civil society, communication networks, and global governance". Annals of the American Academy of Political and Social Science 616: 7893 .

Chowdhury, Mridul. 2008. "The Role of the Internet in Burma's Saffron Revolution.” Research publication by The Berkman Center for Internet and Society at Harvard University 2008 (08).

- Cottle, Simon. 2011. "Media and the Arab uprisings of 2011: Research notes." Journalism 12 (5): 647-659

- Council on Foreign Relations, ed. 2011. The new Arab revolt: what happened, what it means and what comes next. New York: Foreign Affairs.

- Dajani, Nabil. 2011. “Arab Press.” In Arab Media, edited by Noha Mellor, Khalil Rinnawi, Nabil Dajani, and Muhammad I. Ayish, 4566. Cambridge: Polity Press.

- Dajani, Nabil. 2012. "Technology Cannot a Revolution Make: Nasbook not Facebook." Arab Media and Society Issue 15.

- http://www.arabmediasociety.com/?article=782 
- Deibert, R.J. 2009. “The geopolitics of Internet control”. In Routledge Handbook of Internet Politics, edited by A. Chadwick and P.N. Howard, 323-336. London: Routledge.

v Dubai School of Government, ed. 2011. "Civil Movements: The Impact of Facebook and Twitter.” Arab Social Media Report 1 (2).

n http://www.dsg.ae/portals/o/ASMR2.pdf

- Dubai School of Government, ed. 2012. "Social Media in the Arab World: Influencing Societal and Cultural Change?” Arab Social Media Report 2 (1).

n http://www.dsg.ae/en/Publication/Pdf_En/826201211212209 347849.pdf

- Etling, Bruce, Robert Faris and John Palfrey. 2009. "Mapping the Arabic blogosphere: politics, culture and dissent”. Research publication by The Berkman Center for Internet and Society at Harvard University 2009 (06).

- Etling, Bruce, Robert Faris and John Palfrey. 2010. "Political Change in the Digital Age: The Fragility and Promise of Online Organizing." SAIS Review 30 (2): 37-49.

Filiu, Jean-Pierre. 2011. The Arab Revolution: Ten Lessons from the Democratic Uprising. USA: Oxford University Press.

- Ghannam, Jeffrey. 2011. "Social Media in the Arab World: Leading up to the Uprisings of 2011." Report published by the Center for International Media Assistance.

- Ghonim, Wael. 2012. Revolution 2.O: The Power of the People Is Greater Than the People in Power: A Memoir. London: Harper Collins Publishers.

- Gitlin, Todd. 2011. "Sandmonkey: "Too Stupid to Govern Us." Dissent 58 (3): 5-7.

- Gladwell, Malcolm. 2010. "Small Change: Why the Revolution Will Not be Tweeted." The New Yorker, October 4.

n http://www.newyorker.com/reporting/2010/10/04/101004fa_ fact_gladwell

- Gonzalez-Quijano, Yves. 2011. "Las revueltas árabes en tiempos de transición digital. Mitos y realidades." Nueva Sociedad 235: 110121. 
- Habermas, Jürgen. 1992. The Structural Transformation of the Public Sphere. An inquiry into a category of bourgeois society. Cambridge: Polity.

n Hassan, Robert. 2012. "Not Ready for Democracy: Social Networking and the Power of the People. The Revolts of 2011 in a Temporalized Context." Arab Media and Society Issue 15. http:// www.arabmediasociety.com/?article $=788$

- Hijjawi, Aref. 2011. "The role of Al-Jazeera (Arabic) in the Arab Revolts of 2011." Report published by Heinrich Böll Stiftung.

- Hounshell, Blake. 2011. "The Revolution will be Tweetted." Foreign Policy 187: 20-21.

- Idle, Nadia and Alex Nunnis (eds.). 2011. Tweets from Tahrir: Egypt's Revolution as it Unfolded, in the Words of the People Who Made it. London: OR Books.

- Khamis, Sahar, Paul B. Gold and Katherine Vaughn. 2012. "Beyond Egypt's “Facebook Revolution” and Syria's "YouTube Uprising:" Comparing Political Contexts, Actors and Communication Strategies." Arab Media and Society Issue 15. http://www. arabmediasociety.com/?article $=791$

- Khoury, Doreen. 2011. "Social media and the revolutions: how the internet revived the Arab public sphere and digitalized activism." Report published by Heinrich Böll Stiftung.

- Kilani, Mohamed. 2011. La Révolution des Braves. Tunis: Impression Simpact.

- Kraidy, Marwan M. 2002. "Arab Satellite Television between Regionalization and Globalization.” Global Media Journal 1 (1): Article No. 4.

n http://repository.upenn.edu/cgi/viewcontent. cgi? article $=1192 \&$ context $=$ asc $\_$papers

- Kyriakopoulou, Kalliopi. 2011. "Authoritarian states and Internet social media: Instruments of democratization or instruments of control?" Human Affairs 21: 18-26.

- Lynch, Marc. 2011. "After Egypt: The limits and promises of online challenges to the authoritarian Arab State." Reflections 9 (2): 301310. 
Lynch, Marc. 2006. Voices of the New Arab Public: Iraq, AlJazeera, and Middle East Politics Today. New York: Columbia University Press.

Manrique, Manuel and Barah Mikail. 2011. "The role of new media and communication technologies in Arab transitions." Policy Brief 106, published by FRIDE Foundation.

- Mansour, Essam. 2012. "The role of social networking sites (SNSs) in the January 25th Revolution in Egypt." Library Review 61 (2):128-159.

Mason, Paul. 2012. "Why it's kicking off everywhere." Department of Sociology public lecture. London School of Economics and Political Science. January 30.

McCombs, Maxwell E, and Donald L. Shaw. 1972. "Agenda-Setting function of Mass Media." Public Opinion Quarterly 36 (2): 176-187. Mellor, Noha. 2011. "Arab Media: an Overview of Recent Trends." In Arab Media, edited by Noha Mellor, Khalil Rinnawi, Nabil Dajani, and Muhammad I. Ayish, 12-28. Cambridge: Polity Press. Morozov, Evgeny. 2009. "Iran Elections: A Twitter Revolution?" The Washington Post, June 17. Accessed August 15, 2012: http:// www.washingtonpost.com/wp-dyn/content/ discussion/2009/06/17/DI2009061702232.html Morozov, Evgeny. 2011. The Net Delusion. New York: Public Affairs.

- Najjar, Orayb Aref. 2008. "Media policy and law in Egypt and Jordan: continuities and changes." In Arab Media: Power and weakness, edited by Kai Hafez, 217-233. New York: Continuum.

Nanabhay, Mohamed and Roxane Farmanfarmaian. 2011. "From spectacle to spectacular: How physical space, social media and mainstream broadcast amplified the public sphere in Egypt's 'Revolution." Journal of North African Studies 16 (4): 573-603. Nelson, Anne. 2008. "Arab Media: the web 2.o Revolution." Carnegie Reporter 5 (1): 12-23.

Pintak, Lawrence. 2009. "Border Guards of the 'Imagined' Watan: Arab Journalists and the New Arab Consciousness." The Middle East Journal 63 (2): 191-212. 
- Radsch, Courtney. 2008. "Core to Commonplace: The evolution of Egypt's blogosphere.” Arab Media and Society Issue 6.

- http://www.arabmediasociety.com/?article=692

- Richter, Carola. 2008. "The Effects of Islamist Media on the Mainstream Press in Egypt.” In Arab Media: Power and weakness, edited by Kai Hafez, 46-65. New York: Continuum.

- Rinnawi, Khalil. 2011. "Arab Internet. Schizophrenic Trilogy.” In Arab Media, edited by Noha Mellor, Khalil Rinnawi, Nabil Dajani, and Muhammad I. Ayish, 123-148. Cambridge: Polity Press.

- Rinnawi, Khalil. 2006. Instant Nationalism. McArabism, alJazeera and Transnational Media in the Arab World. Lanham: University Press of America.

- Samin, Nadav. 2012. "Saudi Arabia, Egypt, and the Social Media Moment." Arab Media and Society Issue 15. http://www. arabmediasociety.com/?article $=785$

- Sayre, Ben, Leticia Bode, Dhavan Shah, Dave Wilcox, and Chirag Shah. 2010. "Agenda Setting in a digital age: tracking attention to California proposition 8 in social media, online news, and conventional news." Policy \& Internet 2 (2): 7-32.

- Shirky, Clay. 2011. "The Political Power of Social Media." Foreign Affairs 90 (1): 28-41.

- Zhuo, Xiaolin, Barry Wellman, and Justine Yu. 2011. "Egypt: The First Internet Revolt?” Peace Magazine 2 (3): 6-9.

v http://peacemagazine.org/archive/v27n3po6.htm 


\section{ICIP WORKING PAPERS SUBMISSION GUIDELINES:}

\section{International Catalan Institute for Peace (ICIP)}

- The principle purpose of the ICIP is to promote a culture of peace in Catalonia as well as throughout the world, to endorse peaceful solutions and conflict resolutions and to endow Catalonia with an active role as an agent of peace and peace research. The ICIP, seeking consistency between ends and means, is governed by the principles of promoting peace, democracy, justice, equality and equity in relationships between individuals, peoples, cultures, nations and states. It holds the aim of working for human security, disarmament, the prevention and peaceful resolution of conflicts and social tensions, and strengthening the roots of peace and coexistence, peace building and advocacy of human rights.

\section{Objectives of the Publication}

- The ICIP wants to create an open forum on topics related to peace, conflict and security. It aims to open up debate and discussion on both theoretical and contemporary issues associated with the pursuit and maintenance of peace in our world. It strives to connect an eclectic group of voices including career academics, PhD students, NGO representatives, institutional representatives, and field workers and field writers to celebrate ground-breaking and constructive approaches to peace and conflict resolution.

\section{Scope of the Publication (List of Themes)}

- The ICIP is interested in works related to peace, conflict and security research. It aims to provide an innovative and pluralist insight on topics of methodology of peace research, the history and development of peace research, peace education, 
peace-keeping and peace-creating, conflict resolution, human security, human rights, global security, environmental security, development studies related to peace and security, international law related to peace, democracy, justice and equality, disarmament, gender, identity and ethics related to peace, science and technology associated with peace and security.

\section{Audience:}

- The ICP aims to provide accessible, valuable and well-researched material for all those interested in the promotion of peace. Our audience includes fellow academics and researchers, student of peace ands security, field workers, institutional and governmental representatives as well as the general public.

\section{The review process}

- Peer reviewed. Submissions should be sent directly to the series editor (recerca.icip@gencat.cat), who will check whether the paper meets the formal and general criteria for a working paper and will commission a review.

The review procedure is double-blind. The series editor will choose two anonymous reviewers, generally from the Editorial Board, but may also commission an external review from outside the ICIP.

- Reviewers are asked to write a review within a month after having received the paper. Reviews should clearly indicate one of four options: (1) accept without changes; (2) accept with minor changes; (3) allow for resubmission after major changes (4) reject. Options 2 to 4 require some detailed comments. If a paper is accepted (option 1 or 2), reviewers are kindly asked to help authors correct minor linguistic or other errors by making notes in the manuscript. If they use the track changes function for this purpose they should make sure that their comments are anonymized. 


\section{Who may submit working papers?}

- The main criterion for the submission of Working Papers is whether this text could be submitted to a good academic journal.

- ICIP staff and other fellows and visitors affiliated with the ICIP are expected to submit a working paper related to their research while at the ICIP.

\section{Submission System}

- All submissions can be made to the ICIP e-mail address: recerca.icip@gencat.cat with Working Papers - submission in the subject line.

\section{Author Biographical Statement}

- Authors must all provide a short biographical note including full name, affiliation, e-mail address, other contact information if necessary and a brief professional history. This information should be provided on a separate sheet with the title. All other personal references should be removed from the submission to ensure anonymity.

\section{Abstract}

- All papers must include English language abstracts (150 words max.)

\section{Keywords}

- A list of four to six keywords is also required.

\section{Language and Style}

- Authors may submit in Catalan, Spanish or English. The submission must be clearly written and easy to follow with headings demarcating the beginning of each section. Submission must in be Arial 11, double spaced and pages must be numbered. 
- Papers should not be longer than 15.000 words (incl. footnotes and references). Longer papers may be returned with a request to shorten them. Papers that require more extensive presentation of data may add these in an appendix that will count separately. Appendices should, however, present data in a reader-friendly and condensed format.

- Papers that will require extensive linguistic editing will not be accepted for review. Minor linguistic corrections (as well as required revisions) suggested by the reviewer must be implemented by the author before the final editing of the paper.

\section{Footnotes}

- Footnotes may be used to provide the reader with substantive information related to the topic of the paper. Footnotes will be part of the word count.

\section{References}

- The Harvard author-date system. In this system, sources are briefly cited in the text, usually in parentheses, by author's last name and date of publication. The short citations are amplified in a list of references in alphabetical list, where full bibliographic information is provided. Bibliographic references must follow The Chicago Manual of Style ( $15^{\text {th }}$ edition). See a Chicago-Style citation quick guide at:

http://www.chicagomanualofstyle.org/tools_citationguide.html Citation generators:

http://www.workscited4u.com/

http://citationmachine.net/ 


\section{ICIP WORKING PAPERS}

\section{$2012 / 4$}

Las posiciones de los diferentes grupos políticos israelíes sobre la resolución de la situación de los Refugiados by Aritz García Gómez (available in spanish)

\section{$2012 / 3$}

Els esperantistes catalans. Un collectiu pacifista en un món global

by Hèctor Alòs Font

(available in catalan)

\section{$2012 / 2$}

Autonomía comunitaria y caciquismo: identidad étnica, control social y violencia en una comunidad mixe de Oxaca

by Ignacio Iturralde Blanco (available in english and spanish)

\section{$2012 / 1$}

The analysis of the framing processes of the Basque peace movement: The way Lokarri and Gesto por la Paz changed society by Egoitz Gago Anton (available in catalan and english)

\section{$2011 / 8$}

New developments of peace research. The impact of recent campaigns on disarmament and human security by Javier Alcalde and Rafael Grasa (available in english)

\section{$2011 / 7$}

Segregation and the onset of civil war by Lesley-Ann Daniels

(available in catalan and english)

\section{$2011 / 6$}

Mechanisms of Neo-colonialism.

Current French and British

influence in Cameroon and Ghana by Diana Haag

(available in catalan and english)

\section{$2011 / 5$}

Una anàlisi comparativa de la despesa militar espanyola en el molt llarg termini (1850-2009) by Alonso Herranz, Oriol Sabaté and Gregori Galofré-Vilà

(available in catalan and english)

\section{$2011 / 4$}

El foro social mundial y los movimientos antisistémicos by Jordi Calvo (available in catalan and english)

\section{$2011 / 3$}

Cultural Relativism in the Universal Periodic Review of the Human Rights Council by Roger Llovet Blackburn (available in catalan and english) 
INTERNATIONAL

CATALAN

INSTITUTE

\section{FOR PEACE}

GRAN VIA DE LES CORTS CATALANES 658, BAIX

08010 BARCELONA (SPAIN)

T. +3493554 4270 | F. +34935544280

ICIP@GENCAT.CAT | WWW.ICIP.CAT 